Discussion Paper No. 772

\title{
JAPAN'S INTANGIBLE CAPITAL AND VALUATION OF CORPORATIONS IN A NEOCLASSICAL FRAMEWORK
}

\author{
Hiroki Arato \\ Katsunori Yamada
}

February 2010

Revised October 2010

Secondly Revised November 2011

The Institute of Social and Economic Research

Osaka University

6-1 Mihogaoka, Ibaraki, Osaka 567-0047, Japan 


\title{
Japan's Intangible Capital and Valuation of Corporations in a Neoclassical Framework*
}

\author{
Hiroki Arato ${ }^{\dagger} \quad$ Katsunori Yamada ${ }^{\ddagger}$
}

\begin{abstract}
This paper estimates the economic value in the 1980s and 1990s of corporate assets in Japan, including both tangible and intangible assets, based on the neoclassical framework of McGrattan and Prescott (2005). Our estimates use a new micro-data set that comprises the accounting statements of all listed, non-financial companies in Japan. We find that in 1981-86, a period that immediately preceded Japan's so-called "bubble economy", our assessed value of corporate productive assets, net of the value of corporate debt, is approximately equal to the actual stock market value of Japanese corporate equity. The finding differs from previous results based on studies of aggregate data sets or based on studies of micro data sets that neglected intangible capital. We also show that the Japanese ratio of the amount of intangible capital stock to the amount of tangible capital stock is comparable to the analogous ratios for the U.S. and U.K.
\end{abstract}

keywords: Intangible capital, Fundamental value of corporations, Accounting information

JEL classification: E01, E22

*This project started when Yamada belonged to KIER, Kyoto University and was finished after he moved to ISER, Osaka University. Permission for the usage of the Corporate Financial Databank by Development Bank of Japan Inc. is greatly appreciated. An earlier version of this study was circulated under the name "Valuing Japanese Corporations: A New Perspective on Japan's Stock Market "Bubble" of the 1980s." We would like to thank Ellen McGrattan and two anonymous referees for their constructive and detailed criticism that has substantially improved the study. We are also grateful to Carol Corrado, Jonathan Haskel, and Tsutomu Miyagawa for their data provisions, and to David Flath, Ronald Harstad, Tae Homma, Ayumi Ikeda, Tomoyuki Nakajima, Fumio Ohtake, Kazuo Ogawa, and Akihisa Shibata for their helpful comments. Any remaining errors are the sole responsibility of the authors. Yamada acknowledges the research grant provided by the Global COE program of Osaka University, and Grantin-Aid for Scientific Research 21830057. Arato acknowledges the research grant provided by the Global COE program of Hitotsubashi University, and Grant-in-Aid for Scientific Research 18GS0101 which is headed by Tsutomu Watanabe.

${ }^{\dagger}$ Faculty of Economics, Shinshu University.

${ }^{\ddagger}$ Corresponding author: Institute of Social and Economic Research, Osaka University. E-mail: kyamada@iser.osaka-u.ac.jp 


\section{Introduction}

This paper provides a new assessment of the values in the 1980s and 1990s of corporate assets in Japan-including both tangible and intangible assets-based on the neoclassical framework of McGrattan and Prescott (2005). In 1981-86, a period immediately preceding Japan's "bubble economy", our assessed value of corporate productive assets, net of the value of corporate debt, closely approximates the actual stock market value of Japanese corporate equity. The striking implication that equities were correctly priced in Japanese stock markets in 1981-1986 is original, at odds with common perceptions.

As in McGrattan and Prescott, a key assumption of our calculation is that the aftertax rate of return on corporate intangible assets (such as patents, brand names and firm-specific human capital) is in equilibrium equal to that on tangible corporate assets (such as buildings, machinery and equipment). From a newly available micro-data set comprising the financial statements of all private non-financial corporations in Japan, the Corporate Financial Databank (CFD), we extract aggregate measures of corporate pretax profit and investment. Then, these aggregates, observed tax rates, depreciation rates, and real rates of interest, yield an imputation of the market value of intangible corporate assets via equilibrium characterization. Construction of aggregate measures of the market value of tangible corporate assets uses the perpetual inventory method.

This affords a measure of the aggregate ratio of the market value of corporate intangible assets relative to the market value of corporate tangible assets, during the years 198189, which we argue comported with balanced macroeconomic growth. From this ratio, estimated for 1981-89 and assuming Cobb-Douglas production technology, measures of the market value of corporate intangible assets in the subsequent period 1993-97 are imputed.

Consequently, our estimate of Japanese corporate intangible capital in the 1980s falls within a reasonable range. That is, the ratio of aggregate intangible capital stock to aggregate tangible capital stock (0.377) is comparable to the U.S. (0.631 for 1990-2001) and U.K. (0.352 for 1990-2001) ratios as calculated by McGrattan and Prescott (2005). Furthermore, incorporating the value of intangible assets, the ratio of actual corporate market value to the fundamental value of productive capital is approximately one for the "pre-bubble" period, 1981-86, under a reasonable calibration. This suggests that intangible assets are important sources of actual values of Japanese corporate equity, despite being neglected in previous studies of Japanese stock markets.

Yet an unresolved puzzle remains: the Japanese stock price surge during 1987-89 cannot be explained by neoclassical theory (as in McGrattan and Prescott), as the ratio of actual corporate market value to the fundamental values of tangible plus intangible corporate assets is approximately two. Similarly, the transitory increase in Japanese stock prices during 1993-1997 reaches over-valuations of corporate productive assets of about 25 percent.

Our assessment of the values of corporate productive assets in Japan during the 1980s and 1990s offers two advantages over previous studies. The first has been stated: inclusion of intangible assets is original. The market value of intangible corporate capital in Japan is seen to be about one-third that of tangible corporate capital. Neglect of intangible capital is a primary reason why Hoshi and Kashyap (1990) and Hayashi and Inoue (1991) found that the Japanese stock market in 1981-86 was overvalued: their estimates of average 
$q$ were well above one. Hoshi and Kashyap reported that for the period of 1981-87 the q ratio for the median firm in their sample from the Nikkei Financial Tape, adjusting for taxes, averages 1.53 when they employ a narrow definition of capital that should be costlessly adjustable, and averages 1.445 when they treated all assets as capital (p. 379). Using a dataset from the Japan Development Bank, Hayashi and Inoue report that tax-adjusted series of Tobin's q averages 1.245 for the period of 1981-86 (p.740). These figures imply over-valuations in the stock markets, since in the long run equilibrium those q measures must be one or just enough above one to induce the investment needed to offset depreciation.

The second advantage: our study uses micro-data, the financial statements of all corporations, to construct aggregate measures of the value of corporate productive assets, rather than the less reliable statistics from Japan's official System of National Accounts (SNA). The SNA data are less reliable than micro-data because SNA encompasses the entire private sector including many small proprietorships and non-traded firms. The assets of these non-traded firms are subject to errors of measurement an order of magnitude greater. For example, equity values of non-traded firms are recorded at par (face value) in the SNA which is in most instances a substantial underestimate. Reliance on SNA imputations of equity values of non-traded firms may explain why Ando (2002) and Ando et al. (2003) claim that the Japanese stock market in 1980 was substantially undervalued compared to corporate productive assets. For example, Ando et al. (2003) calculated that, for the consolidated corporate sector, average q was 0.32 in 1980. Moreover, no clearly stated, consistent definition of profit is maintained in the SNA dataset profit is, of course, a key variable in estimating intangible assets. A great merit of accounting information is that it allows constructing a model-consistent series of profit levels, providing more reliable estimates of intangible assets, as in McGrattan and Prescott.

The next section describes our framework for assessing the Japanese stock market. Section 3 presents our dataset, describing features such as coverage and relation to the SNA. Parameter calibrations are also presented. We then provide the main results on the pricing in the Japanese stock markets, and offer a possible extension of the present framework. Section 4 concludes.

\section{Analytic framework}

This section presents, for reference, the equilibrium relations developed by McGrattan and Prescott (2005) (hereafter MP) to assess stock valuations. Detailed derivations are in sections 2 and 3 of MP, and a general description is in Appendix B of this paper. The MP model is a two-sector neo-classical growth model. The production side of the economy consists of a representative corporate firm and a representative non-corporate firm. It is assumed that non-corporate sector has standard production technology which needs labor and tangible capital input, and that corporate sector has not only labor and tangible capital but also intangible capital input. The corporate firm maximizes the net profit which is used to pay dividend to equity holders. First order conditions of corporate firm's problem, together with Euler equation obtained in representative household's maximization problem provides the equilibrium condition relating corporate firm's actual value to the sum of fundamental value of tangible capital and that of intangible capital. 
Specifically, MP show that under a balanced-growth path the total value of corporations $(V)$ satisfies

$$
V=\left(1-\tau_{\text {dist }}\right)\left[\left(1-\tau_{x}-\tau_{\delta}\right) K_{m}+\left(1-\tau_{\text {corp }}\right) K_{u}\right]+K^{*},
$$

where

$$
\tau_{\delta}=\tau_{\text {corp }}\left[\hat{\delta}_{x}+\left(1-\hat{\delta}_{x}\right)\left(\frac{\hat{\delta}_{m}}{\left(i+\pi+\hat{\delta}_{m}\right)}\right)\left(\frac{(1+\pi)\left(1-\delta_{m}\right)-1+\hat{\delta}_{m}}{\gamma+\eta+\pi+\hat{\delta}_{m}}\right)\right] .
$$

$K_{m}$ in equation (1) is the tangible capital, and $K_{u}$ represents the intangible capital. $K^{*}$ in the same equation is the tax adjusted value of foreign capital. ${ }^{1}$ We leave explanations of parameters in equation (1) and in equation (2) to section 3.2 in order to save the space.

As can be seen from equation (1), the price of tangible capital for the stockholders is discounted by $\left(1-\tau_{\text {dist }}\right)\left(1-\tau_{x}-\tau_{\delta}\right)$, while the price of intangible capital is discounted by $\left(1-\tau_{\text {dist }}\right)\left(1-\tau_{\text {corp }}\right)$. Distribution tax affects these prices because a dollar reinvested is not taxed, but a dollar distributed is. Subsidies to tangible investment reduce the price of tangible capital because they make investing in tangibles cheaper. The price of intangible capital depends on the corporate distribution tax, and on the corporate income tax rate. This is because investments in intangible capital are expensed and reduce taxable corporate income (MP, p.772).

The intangible capital inputs are not measured; hence we need an estimation formula for intangible capital. The estimation formula of the reproducible cost of intangible capital is derived from the equilibrium condition that after tax marginal return to tangible capital and that to intangible capital are the same. Firm's profit then can be expressed as the sum of contribution from tangible capital and contribution from intangible capital net of intangible investments. On a balanced growth path, we obtain that

$$
K_{u}=\left[\Pi-\frac{i}{\left(1-\tau_{\text {corp }}\right)\left(\gamma+\eta+\delta_{m}\right)} X_{m}\right] /(i-\gamma-\eta),
$$

where $\Pi$ is the net profit and $X_{m}$ is the gross investment in tangible capital.

From equation (1) we obtain the ratio of corporate market value to the predicted fundamental value (RATIO), i.e.:

$$
R A T I O=\frac{V}{\left(1-\tau_{\text {dist }}\right)\left[\left(1-\tau_{x}-\tau_{\delta}\right) K_{m}+\left(1-\tau_{\text {corp }}\right) K_{u}\right]+K^{*}},
$$

The formula accords with the textbook version of Tobin's average q, if we do not consider the reproducible cost of intangible capital $K_{u}$ and accelerated depreciation allowances $\tau_{\delta}$. The quantitative implications of considering the tax-discounted value of intangible capital $\left(1-\tau_{\text {dist }}\right)\left(1-\tau_{\text {corp }}\right) K_{u}$ in the denominator are one of the central topics of this paper. In the following analysis, we normalize these aggregates with output measures of GDP from the SNA.

\footnotetext{
${ }^{1}$ Because of the lack of information on the composition of foreign capital and on foreign tax systems, we use the capital price for Japanese tangible capital. This simplifying assumption and the amount of foreign capital estimated following Hayashi and Prescott (2002) provide the estimate of the predicted fundamental value of foreign capital owned by the private non-financial corporations as 0.015 times the GDP during the 1980s. Note, however, that we will be overestimating the fundamental value of foreign capital owned by the traded private non-financial corporations in the CFD. The coverage of the SNA private non-financial corporate sector is much wider than that of the CFD.
} 


\section{Japanese Economy}

\subsection{Study Period}

The equations presented in Section 2 are applicable to economies on a balanced growth path. In general, assuming homogeneity of degree one in the production function, an economy can be said to be on a balanced growth path if the ratio of capital to output evolves stably over time. Therefore, following Hayashi and Prescott (2002), we calculated the ratio with respect to the entire Japanese economy using the SNA data for 1980-2009. ${ }^{2}$ Figure 1 shows the result. The figure suggests that the capital output ratio evolved in a stable manner during 1981-1989, suggesting that we are justified in applying the equations to this period. Interestingly, the period includes the so-called "bubble era" (December 1986 - February 1991) when stock prices surged. Therefore, we divide the period 19811989 into two sub-periods, 1981-1986 and 1987-1989, for which we provide RATIO results separately.

From Figure 1, it may seem that the capital output ratio evolved in a stable manner during 1993-1997 as well. However, as Hayashi and Prescott (2002) suggested that the whole 1990s is a part of the transition period, we do not regard this sub-period to be on a steady state. This is because this period is not very separated from the former steady state in the $80 \mathrm{~s}$, and since the transition path to a new steady state would not have been completed until 2009 as the figure suggests. Nevertheless, we report RATIO results for 1993-1997, because it is interesting to see what has become of the stock markets valuation after the stock price surge period of the late 80 s.

\subsection{Parameters}

The tax rate for corporate distributions, $\tau_{\text {dist }}$, is computed with data of the personal capital income tax and of the amount of corporate dividends. Note that Japanese corporations rarely make distributions by buying back shares or liquidating operations. Therefore, the relevant tax rate is the tax rate on personal income. For the amount of dividends, we use the "amount of dividends" in the Actual State of Corporate Enterprises Seen from the Taxation Statistics (ASCESTS) published by the National Tax Agency. Similarly, for the amount of dividend tax, we use the "tax on dividends" in the Historical Data published by the National Tax Agency. These figures are on a fiscal year basis and are consistent with the CFD data. We obtain that $\tau_{\text {dist }}=0.226$ for the $1980 \mathrm{~s}$ and $\tau_{\text {dist }}=0.185$ for 1993-1997.

Following Japanese studies such as those by Hoshi and Kashyap (1990) and Nomura (2004), the tax rate on corporate profits, $\tau_{\text {corp }}$, is computed using corporate tax data from the Financial Statements Statistics of Corporations by Industry (FSSCI) published by the Policy Research Institute, Ministry of Finance. This includes the corporate income tax, the prefectural residents' tax, the municipal residents' tax, and the enterprise tax, together with the corporate income data from the Historical Data on corporate profits by the National Tax Agency. These data are available for the private non-financial corporate

\footnotetext{
${ }^{2}$ In this paper, the SNA entries are based on SNA93, which became available after publication of the paper by Hayashi and Prescott (2002), who used data on an SNA68 basis. We use 2009 version of the SNA.
} 
sector on a fiscal year basis and are consistent with the CFD data. For corporate taxes we use "corporation tax, residents' tax and enterprise tax" from the FSSCI, while for corporate profits we use the "amount of income" from the Historical Data by the National Tax Agency. We obtain that $\tau_{\text {corp }}=0.413$ for the 1980 s and $\tau_{\text {corp }}=0.392$ for $1993-1997$.

As Hoshi and Kashyap (1990), Ogawa and Kitasaka (1998), and Nomura (2004) argued, in Japan capital subsidies through investment tax credits for the purchase of new capital goods are quite small. For this reason and because of the lack of relevant information, we consider the investment tax credits to be negligible. The other important form of subsidies on tangible capital is allowed depreciation in excess of economic depreciation. In Japan, "special depreciation" is allowed by the Act on Special Measures Concerning Taxation (Act 26, 1957) in order to promote tangible capital investment. The FSSCI provides information on "special depreciation." We obtained the subsidiary rate on tangible capital, $\tau_{x}$, by dividing the special depreciation series with "gross tangible capital investment" for the private non-financial sector in the SNA. We obtain that $\tau_{x}=0.009$ for the 1980s and $\tau_{x}=0.007$ for $1993-1997$.

As for the allowed rate of immediate expensing of investment, $\hat{\delta}_{x}$, and the allowed rate of depreciation on book value capital, $\hat{\delta}_{m}$, following MP, we assume that $\hat{\delta}_{x}=\hat{\delta}_{m} / 2$. The SNA reports tangible capital depreciation based on the tax code, not the economic code. Therefore, we obtain the allowed rate of depreciation on a book-value basis using the SNA data. $\hat{\delta}_{m}$ is computed as the ratio of "book value depreciation" minus the "replacement cost adjustment" of the subsequent year to "productive capital excluding land holdings." These figures are available for the private non-financial sector in the SNA. The estimated value of $\hat{\delta}_{m}$ is consistent with the coverage of the CFD data. We obtain that $\hat{\delta}_{m}=0.115$ for the 1980 s and $\hat{\delta}_{m}=0.120$ for $1993-1997$. On the other hand, the economic rate of depreciation of tangible capital, $\delta_{m}$, is computed following Hayashi and Inoue (1991) who provide information on economic tangible capital depreciation rates for six capital components of (1) buildings; (2) structures; (3) machinery/equipment; (4) ships; (5) autos/trucks; and (6) tools/fixtures. We constructed a weighted average depreciation rate from the proportions of each capital component in total tangible capital for the period 1981-1989, and set it to the economic depreciation rate, $\delta_{m}$. We obtain that $\delta_{m}=0.076$ for the $1980 \mathrm{~s}$ and $\delta_{m}=0.076$ for 1993-1997. In addition to these depreciation rates, we construct a capital depreciation rate for later use based on the tax code, and that on the economic code, taking into account land holdings in the denominator. Because Hayashi and Inoue (1991) do not report the economic rate of depreciation of tangible capital including land, we take the ratio of the allowed rate of depreciation on a book value including land to that excluding land. Then we take a product of the ratio and the economic rate of depreciation of tangible capital excluding land. Thus, we estimate the economic rate of depreciation of tangible capital including land.

Parameters of the growth rate of labor augmenting technology, $\gamma$, the inflation rate, $\pi$, and the population growth rate, $\eta$ are calculated following Hayashi and Prescott (2002) using the SNA information. Notice that we update their series on an SNA68 basis with the newly available SNA data on an SNA93 basis. The growth rate of labor augmenting technology is defined as the growth rate of total factor productivity, and is obtained as $\gamma=0.053$ for the 1980 s and $\gamma=0.012$ for $1993-1997$. The inflation rate is obtained from the growth rate of the GDP deflator as $\pi=0.012$ for the 1980 s and $\pi=0.001$ for 
1993-1997, and the population growth rate is given by the growth rate of the working-age population as $\eta=0.008$ for the 1980s and $\eta=0.007$ for 1993-1997. Finally, the real interest rate, $i$, is obtained using the equilibrium condition. On equilibrium, from the log preference assumption, the real interest rate $i$ is obtained as $i=[(1+\gamma) / \beta]-1$, where $\beta$ is the subjective discount factor. We borrow $\beta=0.98$ to obtain $i=0.074$ for the $1980 \mathrm{~s}$ and $i=0.033$ for 1993-1997. These figures are in line with those in Chen et al. (2006) and in Braun et al. (2009).

\subsection{Capital Prices}

Figure 2 presents the price of tangible capital, $\left(1-\tau_{\text {dist }}\right)\left(1-\tau_{x}-\tau_{\delta}\right)$, and the price of intangible capital, $\left(1-\tau_{\text {dist }}\right)\left(1-\tau_{\text {corp }}\right)$, during the study period. Interestingly, those prices evolved in a stable manner, unlike the secular large movements seen in the United States and Britain. MP explained movements in corporate valuation in the United States and Britain using the changes in those prices. It is noteworthy that in the case of the Japanese economy, we cannot attribute the surge of actual corporate values in the late 1980s to changes in capital prices.

\subsection{Aggregate Variables}

This study mainly employs micro-level accounting data from the Corporate Financial Databank (CFD) provided by the Development Bank of Japan for the construction of macro entries such as the reproducible cost of tangible capital, total profits, total investment, and total actual corporate value. The data set includes accounting data for all non-financial companies listed on the first or second section of the stock exchanges of Tokyo, Osaka, and Nagoya. Advantages of using the new data set are (i) it covers all traded, non-financial corporations and (ii) it contains detailed balance sheet information so that one can construct more accurate measures of tangible capital and net debt that are evaluated in the stock market, than those calculated using e.g. the aggregate data (SNA) only. As we will see later, constructed series of aggregate variables from the CFD and those from the SNA are very different in levels, despite their trends being very similar.

Consistent historical data for all entries used in our analysis are available for fiscal 1977-2002 from the CFD. (Fiscal years in Japan run from April to March of the next year). Unfortunately, historical data of detailed tangible capital investment is not available before 1977 FY, while the CFD starts with 1956 FY when merely 414 firms are listed. We exploit information for the period of 1956-1976 to obtain the "initial value" of tangible capital stocks at the beginning of 1977 FY. Because firms entered and exited during this period, the number of firms differs from year to year. All in all, data of 2,771 firms were used. All entries in the CFD are based on book value. Therefore, we convert them to a market value basis for each company and then calculate aggregate variables such as capital, investment, etc., by aggregating the firm-level data for each year. The general idea in constructing macro entries is that we exploit all information listed on the debit and credit sides of the balance-sheet. We then examine the ratio of corporate actual market value (credit side) to the predicted fundamental value (debit side) using the MP framework. The detailed

description of how we convert book value entries into market-value entries is in Appendix A. Below, we will construct current-price time series data for all the entries. 


\subsubsection{Actual Corporate Value $V$}

Actual corporate value $V$ is defined as the sum of the value of net corporate debt and the net actual value of outstanding equity. The value of net debt is the difference of non-equity financial liabilities and non-equity financial assets. The net actual value of outstanding equity is the difference of equity liabilities and equity assets, and the value of cross-holding shares must be subtracted from the value of equity liabilities. ${ }^{3}$

The top panel of Figure 3 shows the estimated movements of net debt and the net actual value of outstanding equity for the CFD for 1980-1999. The bottom panel of Figure 3 shows the time series of the aggregate of the corporate value calculated from the CFD data, the movement of the NIKKEI225 stock price index, and the path of the TOPIX, normalizing the value at $1980 \mathrm{FY}$ being one for each aggregate. For a comparison purpose, we provide the information calculated from the SNA as well. As it can be seen from the figure, the trends in these four variables are the same for 1980-1999.

\subsubsection{Tangible Capital $K_{m}$}

For tangible capital $K_{m}$, we consider productive capital, inventories, and land. Figure 4 shows the results of the conversions of the CFD book value entries into the market value entries. As is expected, the market value of tangible capital exceeds tangible capital in a book value basis. Also, the difference between the market value of land and the book value of land is large.

\subsubsection{Intangible Capital $K_{u}\left(X_{m}\right.$ and $\left.\Pi\right)$}

Because we consider the Japanese economy during the 1980s to have been on a steady growth path, we estimate intangible capital $K_{u}$ using the equilibrium relation of equation (3). To do so, we need information on gross investment in tangible capital, $X_{m}$, and on net operating profits, $\Pi$, as explained in Appendix B. For gross investment, we use gross investment in fixed capital [K6260]. ${ }^{4}$

Regarding net profits, total sales profit [K2960] is given as total sales minus sales costs. Here, sales costs include labor cost, tangible capital depreciations, R\&D investment costs, and fixed asset taxes. However, note that sales costs do not include labor costs for corporate headquarters, intangible investment, or other miscellaneous tangible capital cost components. In order to obtain the model-consistent profit series from the accounting information, from the total sales profits we subtract the sum of tangible capital depreciations in the non-operating income section [K3290], in the special account section [K3690], and in the general and administrative expenses (SGA) section [K5810]. We also exclude the amount of land ownership tax [K3310], the amount of business facility tax [K5850], business tax allowance transfer [k5860], labor costs for corporate headquarters in the SGA section [K5750; K5760; K5770; K5780; K5782; K5790; K5800], ${ }^{5}$ intangible

\footnotetext{
${ }^{3}$ In our data set, we cannot distinguish the values of non-cross-holding shares from non-equity long term financial assets. Hence, we count the values of equity assets of non-cross-holding shares as a part of financial assets. This manipulation does not affect the results obtained below at all.

${ }^{4}$ The square brackets show the CFD codes.

${ }^{5}$ [K5750] is wages for workers in headquarters offices, [K5760] is provision for accrued bonuses, [K5770] is the fringe benefit, [K5780] is provision for retirement allowances, [K5782] is retirement benefit expenses,
} 
capital investment of (i) experiments costs [K5820], (ii) R\&D costs [K5822] and (iii) advertisement costs [K5670], and "other SGA costs" [K5910]. ${ }^{6}$ Thereby, we obtain the series of net corporate profits that corresponds to the definition in the MP framework as is given in equation (24) in Appendix B. These variables are flow variables. Therefore, the book values will be equal to current market values.

\subsubsection{Comparison of the CFD with the SNA}

Now that we have exploited all the balance sheet information, we are ready to construct aggregate variables from the CFD. These are necessary for examining the ratio of actual corporate market value to the predicted fundamental value using the framework of MP. Before we proceed, we characterize more features of the CFD data set, since this data set is new to the literature. It is usual to gain an overview of the Japanese aggregate economy using the SNA. We then compare the CFD aggregates with their counterparts in the SNA for the private non-financial sector.

The trend of net actual value of outstanding equity in the SNA resembles that from the CFD as the bottom panel of Figure 3 suggests. In terms of trends, the same thing can be said of other aggregate variables such as tangible capital stocks excluding land, as can be confirmed in Figure 5. At this point, it seems that the CFD actually resembles the SNA. Figure 5, however, shows important level differences between aggregate variables constructed using the CFD, and the corresponding SNA variables in the private nonfinancial sector.

The left top panel of Figure 5 shows the time series of cash holdings by private nonfinancial corporations in the SNA and in the CFD. A noteworthy finding from the panel is that the levels of cash holdings are very different between the two data sets. Because cash is nominal, the differences in the levels of cash holdings will reflect the differences in the coverage of corporations between the data sets. Naturally, the SNA has broader coverage for the private non-financial sector since it includes non-traded corporations. On the other hand, the average coverage of corporations by the CFD is much smaller, being around $20 \%$ of the SNA during the period of 1980-1999. Similarly, the top right panel of Figure 5 shows the movements of tangible capital (excluding land) during 1980-1999. The average coverage of tangible capital of the CFD is around $30 \%$ of the SNA. ${ }^{7}$ The bottom left panel of the figure is net debt. Although the trends of the aggregates from the two data sets are almost identical, again we see a big gap in levels between the data sets.

The above findings confirm that the coverage of private non-financial corporations in the SNA and in the CFD are very different from each other. From the FSSCI data, which is one of the basic statistics for the SNA, we can see that the number of firms in the sector is as many as 15 thousands, while the CFD captures only 2,771 traded corporations at most.

[K5790] is retirement payment, and [K5800] is corporate pension.

${ }^{6}$ In a previous version of the paper, we used a different set of cost components. We, however, subtract more of cost components in the SGA section from the profit in this version of the paper. Such components include for example, advertisement expenses and fringe benefits. Thereby we obtain a model-consistent profit and investment series.

${ }^{7}$ Tangible capital excluding land is on a book value basis for comparison. 
Another remarkable finding from Figure 5 is found in the bottom right panel, which depicts the net actual value of outstanding equity for the SNA and that for the CFD. As can be seen from the figure, despite the differences in the coverage of the two statistics, the levels of net debt equity values are surprisingly comparable between the two data sets.

We can attribute the similarity in these two series to the fact that in the SNA equity values for non-traded private companies are estimated using face values rather than using market values, which is previously pointed out by Ando (2002), and by Hayashi (2006). It is a Japanese business convention that before the major reform of the Commercial Code in 2001, the majority of stock companies, traded or non-traded, issued equities in face values of 20JPY, 50JPY, 500JPY, or 50,000JPY for unit equity, irrespective of their potential market values. The market values of equities were significantly greater compared to the face values, which explains why private corporations no longer issue equities with face values after the reform in 2001. Evaluating equity values of non-traded private corporations using face values, the SNA equity information is erroneous.

External information from the Flow of Funds (FoF) published by the Bank of Japan will be helpful in understanding the issue more. Importantly, the FoF is one of the basic statistics for the SNA, and it provides estimates of debt equity values and cash holdings for private non-financial corporations. It should be emphasized that information of debt equity values in the FoF covers merely the traded corporations, and also that the FoF information for cash holdings covers all the corporations. The SNA covers all the corporations for cash holdings and debt equity. Figure 6 shows the movements of cash holdings (top) and that of debt stock values (bottom) for private non-financial corporations. As can be seen in Figure 6, the trends and levels of cash holdings are almost identical between the SNA and the FoF. On the other hand, it is not natural that the levels of debt equity values resemble each other given that the coverages of the two data sets differ. These patterns provide an indirect but important implication that equity values reported in the SNA are not very useful when researchers would like to examine q-theory: reproducible costs of capital are reported on a market value basis in the SNA, but in a significant part, equity values are reported on a book value basis. Because the proportion of non-traded corporations in the private non-financial sector is significant in the SNA, the total value of debt equity in the SNA is subject to severe under-estimation.

This measurement issue is absent in the micro accounting data set of the CFD whose basic statistics are from annual security reports of traded companies. Also, the suggestion of Ando (2002) relying on the SNA that Japanese stock markets undervalued the value of corporate capital stocks loses ground. Namely, his undervaluation story can result from measurement errors of actual corporate values of non-traded corporations, not from some malfunction in the stock markets as Ando (2002) argued.

\subsection{Estimating Intangible Capital using the MP framework}

We begin by explaining how we estimated intangible capital from the CFD data. Given the calibrated parameters in the top panel of Table 1, and the value of investment relative to GDP, we estimate the contributions of tangible and intangible capital to domestic pre-tax profits. The first column of Table 1 shows the estimation results for intangible capital $K_{u}$ for the period 1981-1989 using the CFD. We find that during the 1980s, 96\% of domestic pre-tax corporate profits are derived from tangible capital. This value is slightly 
greater than that in the case of the United States shown in Table 2 of MP (90.0\% for 1990-2001).

Next, we show the estimate of intangible capital from the SNA data for comparison purposes. It should be remembered that as stated above, the coverage of private nonfinancial corporation sector in the SNA is much wider than the coverage of the CFD.

The estimation of intangible capital from the SNA is possible using the following information on aggregates. In the SNA, inflation adjusted profits $\Pi^{S N A}$ are given by (i) corporate profits ("3. Operating surplus" in "(21) Income and outlay accounts of private and public corporations") minus (ii) adjustments ("Change in assets" in "(2) Reconciliation $c$ account"). ${ }^{8}$ The gross investment series $X_{m}^{S N A}$ are reported in the flow section ("5. Supporting Tables, (22) Capital Finance Accounts of Private and Public Corporations") on a fiscal year basis. They are given by (i) investment in tangible capital ("1. Gross fixed capital formation"). We use GDP for the normalization of these aggregates. The second column of Table 1 shows the estimation results for intangible capital $K_{u}$ for the period 1981-1989 using the SNA. In this case, we see that about $99 \%$ of domestic pre-tax corporate profits are derived from tangible capital.

$K_{u}$ is estimated using Equation (3). The bottom row of Table 1 shows the estimated reproducible cost of intangible capital for each period. Thus, the first column indicates that during the $1980 \mathrm{~s}, K_{u}$ was 0.217 times the GDP level using the CFD information. ${ }^{9}$ This estimate provides the ratio of reproducible cost of intangible capital to that of tangible capital of around 0.373 for the period of 1981-1989. On the other hand, when we rely on the SNA, we obtain that $K_{u}$ was 1.258 times the GDP level for the same period. The ratio of reproducible cost of intangible capital to that of tangible capital from the SNA is around 0.693 .

Hence, the estimate of reproducible cost of intangible capital from the SNA information becomes much greater than the CFD correspondence. The difference between the two estimates looks huge, even after taking the differences in coverage of the two statistics into account. Mechanically, it happens because the ratio of profits to gross investment in the SNA information is greater than that in the CFD. Potential reasons for the difference in the profit to gross investment ratios will be two-fold. The first reason is the difference in the coverage of the two statistics: The CFD data contains only traded private corporations. However, from the FSSCI information, which is a basic statistic for the SNA, we can confirm that the profit to gross investment ratios tend to be greater for private non-financial corporations with greater amount of net wealth, whatever definitions of profits we employ. Hence, the difference in coverage between two data sets will not be the relevant reason. The second reason will be the difference in the definition of aggregate variables of "profits" and "gross investments" between the two statistics. We actually find that differences in the definitions of profits are relevant. Using the detailed accounting

\footnotetext{
${ }^{8}$ See Hayashi (2006) for details on this adjustment of profits.

${ }^{9}$ It is also interesting to see which sector of the economy mainly accumulates the intangible capital. To do so, we divide the companies into heavy industry and light industry, like Hayashi and Inoue (1991). In this study, heavy industry includes manufacturing, farm business, mining, construction, and infrastructure. On the other hand, light industry includes sales, finance (Credit Saison Co. Ltd.), real estate, transportation and communication, and service. For the period of 1981-1989, we see that the heavy industry is endowed with more than $90 \%$ of total intangible capital in the economy. Hence, the intangible capital estimate is mainly accumulated in the heavy industry.
} 
information from the CFD, we can construct a model-consistent series of profits as it is given in Equation (24). On the other hand, we are kept in the dark about the construction of profits in the SNA. ${ }^{10}$

For comparisons, MP estimate that, in 1990-2001, the reproducible costs of domestic intangible capital and domestic tangible capital were 0.65 times GDP and 1.03 times GDP, respectively, in the United States (column 5 in Table 1), and 0.51 times GDP and 1.45 times GDP, respectively, in Britain (column 6 in Table 1). Hence, using the CFD information, we find that the production structure of Japanese economy resembles that of the U.K. $\left(K_{u} / K_{m}=0.352\right.$ for 1990-2001), whereas it is akin to the U.S. economy $\left(K_{u} / K_{m}=0.631\right.$ for 1990-2001) when we rely on the SNA. We suggest that the reality for the production structure lies between the two estimates, despite direct evidence of Fukao et al. (2009) arguing that intangible capital plays a more minor role in Japan, and that all of three developed countries are endowed with non-negligible amount of intangible capital.

We provide other evidence on intangible capital stocks that can be measured directly. Corrado et al. (2006) and Corrado et al. (2009) (hereafter CHS) suggest a perpetual inventory method of directly measuring the amount of intangible capital using information on intangible investments and the depreciation rates for intangible stocks. They consider, for intangible investment, (i) categories of business investment in computerized information, (ii) innovative property, (iii) investment in "economic competencies", and (iv) investment in firm-specific human and structural resources. ${ }^{11}$ According to Corrado et al. (2009), the average ratio of the reproducible cost of intangible capital to GDP in the U.S. 1990-2001 was 0.375 (column 5 Table 1). MP point out that the amount of intangible capital from the method in Corrado et al. (2009) is conservative. This is because the depreciation rates used for R\&D investments are too high (33\% for Computerized information; $20 \%$ for Innovative property; $60 \%$ for Brand equity; $40 \%$ for Firm-specific human capital), and since they may be underestimating some important intangible capital stocks such as firm specific capital. See also Marrano et al. (2009) for U.K. evidence.

Fukao et al. (2009) follow Corrado et al. (2009) and provide a direct measure of intangible capital stock for the Japanese economy. On the last row of Table 1, a direct measure of intangible capital is reported as 0.28 times GDP level for 1985-1989 in Japan after we make coverage adjustment to the CFD statistics. ${ }^{12}$ Unlike the case of the U.S. in

\footnotetext{
${ }^{10}$ We interviewed the national statistical agency of the ESRI about the definition of profits in the SNA. We were informed that the profits in the SNA is akin to current profits in the Japanese accounting system, and that the ESRI adds some adjustments to the legal definition of current profits. Because the way of the adjustments are not open to economists outside of the agency, it is not clear if the profit series in the SNA is consistent with the definition of profits in Equation (24).

${ }^{11}$ See Corrado and Hulten (2010) for updates.

${ }^{12}$ Notice that Fukao et al. (2009) report a direct measure of intangible capital for the whole economy (0.336 times GDP level). In the first column we report intangible capital stock relative to GDP after we adjust the coverage to the one of the CFD for a comparison purpose. To compare our estimates of intangible capital stocks in the Japanese corporate sector, we adjust the coverage of their estimates by using their R\&D investment data from Survey of Research and Development (SRD) published by Statistical Bureau, Ministry of Internal Affairs and Communications. The SRD is used for the estimation of R\&D investment by Fukao et al. (2009), and covers all business enterprises, non-profit institutions and public organizations, and universities and colleges. We assume that intangible capital stocks produced from R\&D investment by non-profit institutions, public organizations, universities, and colleges are distributed to firms proportional to the R\&D investment each firm expends. Hence, all R\&D investment can
} 
McGrattan and Prescott (2005), this figure and our theoretical prediction of the intangible capital stock resemble each other.

\subsection{Estimation of RATIO}

Table 2 shows our estimation results for RATIO using equation (4). Notice that we report results from the CFD information only. This is because actual corporate values are under-estimated in the SNA so that the "undervaluation results" of Ando (2002) are exaggerated when we include the fundamental value of intangible capital in the denominator of equation (4). ${ }^{13}$ Interestingly, our study period includes the so-called "bubble era" (December 1986 - February 1991) when stock prices surged. Therefore, we divide the period 1981-1989 into two sub-periods, 1981-1986 and 1987-1989, for which we provide separate RATIO results, while keeping $K_{u}$ the same for two sub-periods.

We report the results for the period of 1993-1997, in addition to those for the 1980s, to provide casual evidence on the stock market situation after the so-called "bubble period." The tax rates fluctuated only a little during the 1990s as shown in Figure 2, and equation (4) may be justifiably exploited for the sub-period. On the other hand, the interest rate and the technological growth rate declined during the 1990s. We do not exploit Equation (3) in estimating intangible capital for the 1990s, since the equilibrium relation requires constancy of the interest rate and the technological growth rate. ${ }^{14}$ Hence, regarding 1993-1997, we infer the re-producible cost of intangible capital using the production structure of the model. Specifically, we specify that the homogenous production function of the final goods is of Cobb-Douglas type. Assuming that $\delta_{m}=\delta_{u}=\delta$ and given the fact that capital prices are stable over the study period, it easy to show that the growth rates of $K_{m}$ and $K_{u}$ are the same along a transition path. Hence, we obtain that an expansion path of tangible capital $K_{m}$ and intangible capital $K_{u}$ is straight in the $\left(K_{m}, K_{u}\right)$ plane over the transition period of capital deepening after 1990. Evidence from the U.S. in MP may support our strategy. In Table 4 , MP reported that the $K_{m}$ to $K_{u}$ ratio was 0.717 for the 1960s, and was 0.631 for the 1990s. From this, we speculate that the production structure changes only gradually when it happens. Also, notice that the series of capital share estimated using the SNA information is highly stable after 1980 around the value of 0.35. We thereby estimate the amount of intangible capital by assuming that the amounts of tangible capital $K_{m}$ and that of intangible capital $K_{u}$ grow in parallel. This provides an estimate of $K_{u}$ for 1993-97 as 0.212 times the GDP level.

In this paper, we provide results with and without land estimations for RATIO, because Japanese economists sometimes prefer not to include land when examining asset pricings in the macro economy. For example, see Ando (2002). ${ }^{15}$ However, the results in

be regarded as expended by firms. Next, to estimate the coverage-adjusted R\&D investment in the SRD, we use data of total sales across firm size. From the SRD, we can obtain the data on R\&D investment by size of sales. We use the coverage adjusted investment series to obtain the coverage ratio of the CFD to the SRD. Finally, we assume that intangible capital stocks are proportional to R\&D investment and obtain the direct (and corresponding) measure of intangible capital stock.

${ }^{13}$ Using the SNA information, we find that $R A T I O=0.240$ from a without-land-calibration for $1981-$ 1989 (not shown).

${ }^{14}$ See also Chen et al. (2006) and Braun et al. (2009) for the movements of the real interest rates and savings in Japan after the 80s.

${ }^{15}$ Using aggregate data, Ito and Iwaisako (1995) and Nakajima (2008) examined Japanese stock markets 
the left panel and in the right panel of Table 2 suggest that our findings should remain unchanged, irrespective of inclusion of land into our considerations.

The upper part of Table 2 shows parameter values for the prices of tangible and intangible capital. As shown in Figure 2, the prices of tangible and intangible capital evolved in a stable manner until the end of the 1990s. The middle part of Table 2 shows our estimates of reproducible costs and fundamental values of tangible and intangible capital, as well as our estimates of fundamental values of foreign capital and actual market values of private non-financial corporations in the CFD. ${ }^{16}$

Finally, the lower part of the table shows the estimates of RATIO for two cases. RATIO corresponds to the MP framework and takes the fundamental value of intangible capital into account. On the other hand, the second measure of RATIO is the case when we do not consider the fundamental value of intangible capital in equation (4). We call it Ando's RATIO. The finding here is that our RATIO falls within a reasonable range around one for the period of 1981-1986. So, the framework of MP works very well using the Japanese data set as it does in the cases of the U.S. and U.K. applications. We can compare our results with previous studies on Japanese stock markets that use micro data sets. Hoshi and Kashyap (1990) and Hayashi and Inoue (1991) have sought to analyze Japanese stock prices by estimating the ratio of actual corporate market value to the theoretically-predicted fundamental value, Tobin's average q. Hoshi and Kashyap (1990) report that the q ratio for the median firm in their sample from the Nikkei financial tape is around 1.56 on the average for the period of 1981-1987 when the q ratio is adjusted for taxes (p. 379, Hoshi and Kashyap 1990). Similarly, using the data set from the Japan Development Bank, Hayashi and Inoue (1991) report that tax adjusted series of Tobin's average q is around 1.245 on the average for the period of 1981-1986 (p.740, Hayashi and Inoue 1991). If we rely on these measures, we see that the Japanese stock markets tended to overassess the fundamental value of corporations. However, our results show that the ratio of actual market values of corporations to the fundamental values of corporations fall within a reasonable range around one, when we consider the fundamental value of intangible capital. In this sense, our finding goes on with fine-tuning with respect to the previous findings of "over-valuations," by considering intangible capital.

When we see Ando's RATIO for the same period, we find that the actual market value of corporations overshoot the predicted fundamental value of corporations. First, this implies that intangible capital is an important source of corporate values in the Japanese stock markets. Second, this finding is a sharp contrast with the undervaluation story of Ando (2002) and Ando et al. (2003). They argue that the market valuation of Japanese corporations is far below their reproduction costs. For example, Ando et al. (2003) report that for the consolidated corporate sector, a measure of Tobin's average q ranges from a low of 0.32 in 1980 to a high of 0.52 in $1998 .{ }^{17}$ As stated above, it is well known that the corporate stock values of private non-listed corporations are severely underestimated in

with special focus on land and secular changes in TFP, corporate taxes, and marginal taxes on land holdings. Stock prices predicted from these models are found not to fit the data well.

${ }^{16}$ The estimates of reproducible cost of tangible capital $K_{m}$ are based on the CFD data, the construction of which is documented in Appendix A. Those of intangible capital $K_{u}$ are from Table 1.

${ }^{17}$ Notice that Ando et al. (2003) do not make tax adjustments in deriving these figures. If we apply capital prices and the dividend tax rate of the 1990s calibrated in this paper to the SNA aggregates reported in Ando et al. (2003), we obtain that Tobin's average q for 1998 is around 0.717. 
the SNA (see, e.g., Ando 2002; Hayashi 2006). This is because for un-traded corporations, which are a major component of corporations in the SNA, the value of outstanding stocks is estimated with a face value basis. Also, the coverage of the private sector in the SNA includes public enterprises. Because of these features of the SNA, the under-valuation story loses its grounds. Since we are focusing on the traded companies using the CFD, our estimates of RATIO from the CFD will provide a reliable view on the Japanese stock markets phenomena.

So far we employed the framework of MP in investigating the Japanese economy. This is because the Japanese tax system has almost the same structures as the U.S. and the U.K. systems. Here we consider an exceptional tax system that used to be adopted in Japan, but has been absent in the U.S. and the U.K. economies (meaning that MP did not consider). The tax system is the two tier tax on corporate retained earnings. The two tier tax is the preferential tax on corporate earnings which were paid as dividends. This tax was introduced in order to encourage firms' equity finances and dividend payments and was kept lower than the corporate income tax. The tax was abandoned in $1990{ }^{18}$

Following Alpanda (2011) we extend the MP framework to incorporate the two tier tax rate, and re-assess the ratio of actual market corporate value to the predicted fundamental value of corporations. When the two tier tax is available for corporations, the amount of dividend paid by corporations is given as

$$
\begin{aligned}
& d_{1, t}=p_{1, t} y_{1, t}-x_{1 m, t}-x_{1 u, t}-w_{t} n_{1, t}-\tau_{1 k} k_{1 m, t} \\
- & \tau_{1}\left[p_{1, t} y_{1, t}-\hat{\delta}_{1 m} \hat{k}_{1 m, t}-\hat{\delta}_{1 x} x_{1 m, t}-x_{1 u, t}-w_{t} n_{1, t}-\tau_{1 k} k_{1 m, t}\right]+\tau_{x} x_{1 m, t}+\left(\tau_{1}-\tau_{d i s t}^{c}\right) d_{t}
\end{aligned}
$$

where $\tau_{\text {dist }}^{c}$ is the preferential tax rate on corporate earnings which were paid as dividends. The last term of $\left(\tau_{1}-\tau_{\text {dist }}^{c}\right) d_{t}$ is the amount of corporate profits saved by the tax shelter. With this equation, equation 4 can be rewritten into

$$
V=\left(1-\tau_{\text {dist }}^{\prime}\right)\left[\left(1-\tau_{x}-\tau_{\delta}\right) K_{m}+\left(1-\tau_{\text {corp }}\right) K_{u}\right]+K^{*},
$$

where $\tau_{\text {dist }}^{\prime}=\left(\tau_{\text {dist }}+\tau_{\text {dist }}^{c}-\tau_{\text {corp }}\right) /\left(1+\tau_{\text {dist }}^{c}-\tau_{\text {corp }}\right) .{ }^{19}$ In this paper, we borrow the ratio of the corporate tax rate to the two-tier tax rate from Alpanda (2011) to obtain that $\tau_{\text {dist }}^{c}=0.3356$ for the 1980 s from the corporate tax rate calibrated in this paper. We then replicate the procedure of estimating RATIO with the modified effective tax rate on corporate distributions for the sub-periods of 1981-1986. We obtain the modification results at around $17 \%$ increase in RATIO, giving a slight impression of "over-valuation."

Next, regarding the sub-period of 1987-1989 when the stock price surged, RATIO is found to be too high. ${ }^{20}$ Hence, as Hoshi and Kashyap (1990) and Hayashi and Inoue (1991), the Japanese stock price surge in the late 1980s remains for us an unsolved puzzle: we find that incorporating intangible capital into a neoclassical model cannot explain the stock price surge in the late 1980s.

\footnotetext{
${ }^{18}$ See Ishi (2001) for the detailed descriptions on the two tier tax system.

${ }^{19}$ See Alpanda (2011) for the derivation of $\tau_{d i s t}^{\prime}$.

${ }^{20}$ Using aggregate data from the Quarterly Report of Financial Statements of Incorporated Business, Ogawa and Kitasaka (1999) found that after 1986, the discrepancy between Tobin's average q and marginal q became large. They argue that this may represent evidence of a stock price bubble during this period. Fukuta (2002) examined the necessary conditions for the absence of rational bubbles, and showed that Japanese stock prices and dividends satisfy the necessary conditions.
} 
Regarding the stock price surge during the so-called "bubble-period," Hoshi and Kashyap (1990) and Hayashi and Inoue (1991) argue that pricing in stock markets was "correct" both during the pre-bubble period and during the bubble era. They suggested that the reason for this was that the stock price surge during the late 1980s was cancelled out by the price surge in land (namely, the increase in fundamental value of tangible capital). These studies, however, leave an open question as to why the land price increased so much. Recently, Alpanda (2011) has opened a new window to understanding the movement of Japanese land prices in the framework of a neoclassical growth model akin to MP. He introduces the role of corporate bonds, and allows the possibility that corporations issue land-collateralized debt to reduce their tax liabilities. The government follows a land taxation policy that is countercyclical to land prices. With these features, the collateral use of land and countercyclical land tax policy introduce a substantial magnification mechanism for asset prices. The movement of land prices can be partly explained by the model. The framework of MP abstracts from the role of corporate debts and from the tax shelter role of the land collateralization. A natural extension of the present framework would be to introduce corporate debts and the collateral use of land into the framework of MP to explain the Japanese stock price movement throughout the 1980s.

Finally, we refer to our parsimonious measure of RATIO for the 1990s. We see from Table 2 that RATIO is around 20\% higher compared to the ones for 1981-1986, with or without taking land into accounts. The mid $90 \mathrm{~s}$ is known as the period of recovery in stock prices after the sharp decline in the early 90s. The recovery will be because of change in household expectations after the so-called "kouzou-kaikaku" (structural reform) by the Koizumi cabinet, and after IT revolution as highlighted by Hayashi and Nomura (2005). We find that the stock price increase in the mid 90s was actually a slight over-valuation of the fundamental values of corporate capital stocks.

\subsection{Robustness Check}

In the above analysis, real interest rates were calibrated with the assumption that $\beta=$ 0.98. It will be useful to provide a sensitivity test on the choice of the subjective discount factor, or equivalently, of the real interest rate. Here we provide additional results for $K_{u}$ estimation for 1981-1989, using three different sources of the real interest rates, (i) a time series of the real interest rate calibrated from the SNA information using the method in McGrattan and Prescott (2004), (ii) the real interest rate from an external source, and (iii) the real interest rate from the method of Hayashi and Prescott (2002). Regarding (i), we constructed the productivity of capital by dividing after-tax capital income by the stock of tangible capital for the private non-financial sector in the SNA. We obtain that $i=0.0791$ for 1981-1989. With respect to (ii), we refer to the long term prime interest rate for city banks in the Bank of Japan Website, and to the CPI inflation rate. We calculate that $i=0.0548$. Hayashi and Prescott (2002) estimate the subjective discount factor with the growth rate of household consumption in the SNA, providing that $\beta=0.9693$. From this we obtain that $i=0.0858$.

When we use the real interest of 0.0791 , we obtain that $K_{u}=-0.107$ times the GDP level from the CFD, and is 0.430 times the GDP level from the SNA. The negative value of $K_{u}$ does not make any sense, and the SNA estimate is reduced by $70 \%$, compared to our benchmark estimate. Second, when we apply $i=0.0548$, we have $K_{u}=-3.401$ times 
the GDP level from the CFD and $K_{u}=-7.944$ times the GDP level from the SNA. Third, when we apply $i=0.0858$, we have $K_{u}=-0.334$ times the GDP level from the CFD and $K_{u}=-0.151$ times the GDP level from the SNA. Obviously, these estimates of $K_{u}$ are not encouraging. Hence, a sensitivity issue arises as a limitation of imputation method using the equilibrium equation (3), which is intrinsically sensitive to changes in the real interest rate. Here, our claim is not that results from the neo-classical model are fragile, but that economists should focus on reliable calibrations to obtain convincing results. Given the plausible results in MP and the results in this paper, we believe that the MP framework is a nice benchmark model to estimate intangible capital when we focus on the right periods of steady growth.

Then, given plausible estimates of intangible capital and an assumption of CobbDouglas production function, we can obtain capital share parameters for tangible capital and that for intangible capital. We think that these are exactly what we want. When capital share parameters are available, we can infer the amount of intangible capital for when the economies are not on the steady growth path without exploiting the equilibrium conditions in equation (3). This is a great merit since information of tangible capital is easily obtained, and usually it takes a long time before the production structure of an economy has changed.

\section{Conclusion}

A consensus has emerged that intangible capital plays a crucial role in explaining important economic phenomena. Examples include secular movements of stock prices in the United States and Britain (McGrattan and Prescott 2000, McGrattan and Prescott 2004, McGrattan and Prescott 2005), the difference of profit performance between domestic and foreign operations of U.S. corporations (McGrattan and Prescott 2010a), and the business cycles in the United States in the 1990s (McGrattan and Prescott 2010b).

Employing the methodology developed by McGrattan and Prescott (2005), we examined Japanese stock market phenomena in the 1980s and 1990s using a micro data set from the Corporate Financial Databank, with which we constructed aggregate variables such as capital stock and actual corporate value in a precise manner. When we consider the fundamental value of intangible capital, our estimates of the ratio of corporate market value to the predicted fundamental value falls within a reasonable range of around one, for the period of 1981-1986. This finding contrasts with previous studies of Japanese stock. Hoshi and Kashyap (1990) and Hayashi and Inoue (1991) who used micro data sets as in this study reported estimates of Tobin's average q of 1.56 and 1.25 for the early 1980s, suggesting that the stock market over-valued corporations relative to their fundamental values. We show that the previous results overvaluation result is caused by neglecting intangible capital, which is an important component of the capital stock. Our finding also contrasts with that of Ando (2002) and Ando et al. (2003), who, using data from the SNA, argued that the Japanese stock markets undervalued the corporate capital stock. For example, Ando et al. (2003) calculated that for the consolidated corporate sector, Tobin's average q that did not take account of fundamental value of intangible capital was 0.32 in 1980. We show that the previous result from aggregate SNA data of

undervaluation probably reflects errors in measurement of the actual value of smaller and 
non-traded corporations.

However, we find that incorporating intangible capital into a neoclassical model cannot explain the stock price surge in the late 1980s. Regarding the stock price surge during the so-called "bubble-period," Hoshi and Kashyap (1990) and Hayashi and Inoue (1991) argued that pricing in stock markets was correct both during the pre-bubble period and the bubble era. They suggested that the reason for this was that the stock price surge during the late 1980s was cancelled out by the price surge in land (namely, the increase in the fundamental value of tangible capital). These studies, however, left an open question as to why the land price increased so much. A recent study by Alpanda (2011) has suggested an approach to solve the question. A natural extension of the present framework would be to introduce corporate debt and the collateral use of land as in Alpanda (2011) into the framework of McGrattan and Prescott (2005) to explain the Japanese stock price movements throughout the 1980 s and the 1990 s.

\section{Appendicies}

\subsection{Appendix A}

\subsubsection{Actual Corporate Value $V$}

We obtain the total market value of corporations, $V$, as follows. In the Japanese accounting system, the debit side of the balance sheet consists of broad categories of quick assets, inventory assets, other liquid assets, allowances for doubtful accounts, tangible capital, intangible capital, other investment assets, and deferred assets in order of appearance. Among these entries, the information of inventory assets, tangible capital, and intangible capital are respectively used in constructing a series of values for tangible and intangible capital. Hence they are not considered here.

In the CFD data, financial assets consist of quick assets [K0870], other liquid assets [K1130], allowances for doubtful accounts [K1270], other investment assets [K1760] and deferred assets [K1870]. Financial Statements Rules, Act 8 regulates that financial commodity items (except for affiliates' shares) are encouraged to be listed on balancesheets in a market value basis. In this paper we assume for these financial asset variables that the book value variables are equal to the market value variables. ${ }^{21} \mathrm{We}$ aggregate the above items to obtain the total value of a financial asset. In doing so, we need to exclude the book value of own shares [K0980], shares of parent company [K0990], and affiliates' shares [K1590] from the value of financial assets in order to take into account share cross-holdings. The Japanese financial statements are not consolidated for private accountings. $^{22}$

The credit side of the balance sheet consists of the liability part and the net worth part. Broad categories in the liability part include current liabilities, long term liabilities, and

\footnotetext{
${ }^{21}$ See also Hayashi and Inoue (1991).

${ }^{22}$ More precisely, the value of own shares [K0980] is subtracted from the value of financial asset, and also from the actual values of outstanding equity, while the value of parent company [K0990] is subtracted from the value of financial asset, and also from the value of financial liability. Own shares [K0980] and shares of parent company [K0990] are included in quick assets [K0870], and affiliates' shares [K1590] is a part of other investment assets [K1760].
} 
special allowances. Broad categories in the net worth part include shareholders' equity and the amount of difference for reappraisal. As for financial debts in the CFD, we consider current liabilities [K2290], long-term liabilities [K2520], special allowances [K2620], earned reserves [K2670], amount of difference for land reappraisal [K2672], amount of difference for marketable securities reappraisal [K2674], other surplus [K2680], and amount of difference for other marketable securities reappraisal [K2782]. Though earned reserves [K2670] and the last four items of amount of difference for reappraisal come from the net worth part, we consider them as a part of financial debts. Thereby, we can exploit all the information listed in the balance sheet. On the other hand, capital fund [K2640], amount paid for newly issued stocks [K2650], capital reserves [K2660], and change in treasury stock [K2784] are not counted in the financial debts. This is because they are related to the value of outstanding equity. We have to avoid overlapping valuations when we later estimate the actual values of outstanding equity with information of the stock prices and the number of shares issued. We assume that the book value variables of financial liabilities are equal to the market value variables. ${ }^{23}$

Therefore, the value of net debt is given by financial liabilities minus total financial assets, multiplied by one less the tax rate on distributions. ${ }^{24}$ Notice that the value of net debt thus constructed does not include the value of cross-holding shares.

Regarding equity, we have information on the highest and the lowest stock price within the fiscal year, [K0370] and [K0380], respectively, and information on the number of shares outstanding [K5440]. Thus, we can estimate the series of actual values of outstanding equity by using the product of the average of the highest and the lowest prices and the number of shares issued in the sample. ${ }^{25}$ However, as pointed out by Hayashi and Inoue (1991), because the Japanese financial statements are not consolidated, the market value of affiliates' stocks is included in the above estimated total actual value of corporate equity. We need to subtract the value of cross-holding shares to calculate the actual market value of non-financial listed companies owned by households.

We estimate the value of shares net of the cross-holdings using an external information of "Share-ownership Survey" (SS) which is jointly published by the domestic stock exchanges (Tokyo, Osaka, Nagoya, Fukuoka, and Sapporo). In this data set, information of proportions of equity ownership by business sector for the listed non-financial corporations is available. Hence, we can obtain a cross-holding proportion by looking at the values of shares of non-financial corporations held by the same sector. The ratios for the 1980s and for 1993 - 1997 are slightly over $20 \%$ and are fairly stable. We can estimate the actual values of outstanding equity net of cross-holding values as the total actual value of corporate equity times one minus the cross-holding ratio. It is noteworthy that the net equity values thus constructed are underestimating the true values, because the "value of shares of listed nonfinancial corporations held by business corporations" in the

\footnotetext{
${ }^{23}$ Hayashi and Inoue (1991) found that for Japanese traded corporations the average maturity period for long term bank loans, which are the dominant component of long term debt, is relatively short, and that long term debts are about one half of short term debts. Hence, the discrepancy between the market value and the book value of financial debts will not be an issue.

${ }^{24}$ See footnote 23 of MP for details on this point.

${ }^{25}$ We subtract the value of self-holdings of shares [K0980] from the above estimated series of actual values of outstanding equity. [K0980] is recorded in fiscal years after 1986, and it accounts for at most $0.1 \%$ of total stock values for each fiscal year.
} 
SS includes the stock values held by non-traded corporations. This under-estimation issue will be negligible, however, given the small amount of equity holdings by non-traded corporations.

\subsubsection{Tangible Capital $K_{m}$}

For tangible capital $K_{m}$, we consider productive capital, inventories, and land.

We follow Hori et al. (2006) in considering productive capital. Regarding the CFD data, we have six categories for productive capital: (i) buildings [K1300], (ii) structures [K1310], (iii) machinery/equipment [K1320], (iv) ships [K1340], (v) autos/trucks [K1350], and (vi) tools/fixtures [K1360]. We consider fiscal 1977 as the benchmark year, because after the year consistent historical data for tangible capital investment in these six categories is available. Before fiscal year 1977, the CFD reports merely the total tangible capital investment, while it reports the stocks of detailed six tangible capital components in a book value basis. The CFD starts with $1956 \mathrm{FY}$ and we exploit information before 1977 FY to obtain the initial values of tangible capital stocks and inventory at the beginning of benchmark year of 1977 . The following explains our procedure by a run of the item.

1. The CFD starts with $1956 \mathrm{FY}$, setting the reported book values of six capital components in this year as the market value. They are aggregated across components and across companies to form the aggregate tangible capital stock in market value basis. Note that only 414 companies are listed on the CFD in the year.

2. We construct a simple weighted average depreciation rate to run a perpetual inventory method for total tangible capital from $1956 \mathrm{FY}$ to $1976 \mathrm{FY}$. The depreciation rates for six capital components are borrowed from Hayashi and Inoue (1991). The weights are taken from the proportions of capital components among the total tangible capital in fiscal year 1956.

3. With respect to companies that appeared after $1956 \mathrm{FY}$, the values in the year when they appear are considered to be the market values.

4. With the price series on investment taken from the Bank of Japan; the weighted average depreciation rate obtained above $(7.88 \%)$; the initial capital stock values in 1956 FY; and information regarding the total tangible capital investment [K6260], we run a perpetual inventory method for the aggregate tangible capital stock. After we add the real investment in $1976 \mathrm{FY}$, we are left with the beginning of period value of total tangible capital in fiscal year 1977.

5. We take into account the number of listed companies in the CFD. In $1976 \mathrm{FY}$, we have 1,533 companies, whereas in $1977 \mathrm{FY}$ we have 1,544. We assume that the average sizes of the firms in these two years are the same, and we obtain our initial value of total tangible capital stocks in $1977 \mathrm{FY}$ by multiplying the above obtained variable by $1544 / 1533=1.0071$. Finally, we take the ratio of the total tangible capital, which is in market value basis, to the sum of the book values of six capital components in $1977 \mathrm{FY}$ reported in the CFD to obtain the market value to the book value ratio in tangible capital of 2.7601 for the fiscal year 1977 . 
6. We then take the products of 2.7601 and the book values of the six capital components in the CFD in the fiscal year of 1977, providing the initial values of the six capital components for the perpetual inventory method after $1977 \mathrm{FY}$.

7. We repeated the same procedure for all inventories. The multiplier is 2.804 .

As for firms that appear in the CFD data after 1977, the values in the first year in which they appear are assumed to be the market values. These simplifying assumptions are used due to limitations regarding the availability of data. Next, we obtain the book value gross investment for each category from the CFD for (i) buildings [K6270], (ii) structures [K6280], (iii) machinery/equipment [K6290], (iv) ships [K6300], (v) autos/trucks [K6310], and (vi) tools/fixtures [K6320]. Then, for each company, we convert the book-value investment figures to real investment figures by dividing the former by the relative price of capital. The relative price of capital in the benchmark year for the company is set to one. ${ }^{26}$ Next, we use the following depreciation rates for the six categories taken from Hayashi and Inoue (1991) and Hori et al. (2006): (i) 4.7\%, (ii) 5.64\%, (iii) 9.489\%, (iv) $14.7 \%$, (v) $14.7 \%$, and (vi) $8.838 \%$. Then for each company, from the capital stock in the benchmark year, we construct the real tangible capital series by the perpetual inventory method using the real investment obtained in the manner described above and the depreciation rates. We divide the capital series for each company by the relative price for the appropriate benchmark year. Then we aggregate the real capital obtained in this way across all companies. Doing so, we obtain the real capital stock historical data for which the benchmark year for all firms is set to 1977. Finally, we multiply the aggregate capital stock with the price series for capital, thus obtaining capital stock in current prices.

With respect to inventories, we follow Hoshi and Kashyap (1990) to construct the market value series. We set the benchmark year for each firm in the same way as we did for productive capital. Again, the book values in the benchmark year are assumed to be market values. In general, the book value of inventories can differ greatly from the market value depending on the method of inventory valuation. Therefore, we divide our CFD inventory categories into three parts: (i) inventories for which information about the valuation method is available, (ii) inventories for which information about the method of valuation is not available, and (iii) land for sale. Here (i) includes inventories of commercial goods [K1040], inventories of finished products [K1060], inventories of half-finished goods [K1070], inventories of products in progress [K1080], inventories of materials [K1100], and inventories of merchandise and supplies [K1110]. Whereas, (ii) includes inventories of other goods [K1120]. As stated in Hoshi and Kashyap (1990), when inventories are evaluated in the "last in, first out" (LIFO) manner, the book value differs greatly from the market value. Alternatively, if inventories are evaluated in any other manner, the book value will approximate the market value. Therefore, for inventories in (i), we assume that the book value equals the market value if firms do not follow the LIFO method of inventory valuation. ${ }^{27}$ We also use this method to calculate category (ii) inventories in

\footnotetext{
${ }^{26}$ The price of capital is taken from the Bank of Japan. Specifically, we use the price of "construction materials" for (i) buildings and (ii) structures, the price of "machinery and equipment" for (iii) machinery/equipment and (vi) tools/fixtures, and the price of "transport machinery" for (iv) ships and (v) autos/trucks.

${ }^{27}$ We can see how firms value each inventory item using the CFD information [K4610] - [K4690].
} 
current prices. With respect to category (iii), land for sale [K1050], we have neither information on the inventory valuation method nor on a price index. Hence, we assume that book values equal market values

On the other hand, when firms follow the LIFO method with respect to category (i) inventories, we construct market value inventory series as follows. First, if an inventory item increases from time $t-1$ to time $t$, the addition is assumed to be recorded in the books at the current price. Hence, the inventory stock at time $t$ is the sum of the inflation adjusted value of the inventory carried from time $t-1$ to time $t$ and the book value of the addition. Second, when the book value of a firm's inventory decreases from time $t-1$ to time $t$, we assume that the cleared inventories are one year old and make the appropriate correction for inflation for the stock of inventory carried from time $t-1$ to time $t$. Finally, if a firm uses both the LIFO and another inventory valuation method for an inventory category, then we assume that half of the inventories are valued using the LIFO method.

Information related to land holdings is available in the CFD under [K1390]. Following Ogawa and Kitasaka (1998), we convert the book value variables into market value variables as follows. The SNA provides information on the estimated market value land holdings of the private non-financial corporate sector. In addition, the Financial Statements Statistics of Corporations by Industry (FSSCI) published by the Policy Research Institute, Ministry of Finance, provides book value information on land holdings for the sector. Theoretically, we could obtain the market-to-book-value ratio by dividing the SNA values by the FSSCI values if the coverage of corporations were identical in the two statistics. However, in practice, the coverage is known to be different. Therefore, we need to adjust the two sets of data by calculating the coverage ratio. Both the SNA and the FSSCI contain information on cash holdings for the non-financial corporate sector. Because cash is nominal, the difference in the amount of cash holdings between the two statistics will reflect the difference in coverage. Consequently, we can adjust for the difference in coverage and obtain the appropriate market-to-book-value ratios for land holdings. Finally, we obtain our market-value land holding series by multiplying the CFD land holding with the ratios.

Next, we consider "other capital," which is the sum of tangible capital for rent [K1370], other productive capital [K1380] and other tangible capital [K1410]. Because we have no information to obtain market value series, we assume that the book value variables are equal to the market value variables. We obtain $K_{m}$ for each year by aggregating the above capital entries across firms.

Finally, regarding the amount of foreign capital, we have no clues in the CFD data. Hayashi and Prescott (2002) estimated the amount of foreign capital for the whole Japanese economy using the SNA, by regarding the current account balance (the sum of net exports and net factor income from abroad) to accumulations of foreign capital. ${ }^{28}$ We replicate the procedure using information on an SNA93 basis. Note that the estimate of foreign capital thus constructed includes the amount of capital owned by the households, by the government, and by the private financial sector. We estimate the amount of foreign capital owned by the private non-financial sector by using the product of the amount of

\footnotetext{
${ }^{28}$ Hayashi and Prescott (2002) assume that the amount of foreign capital in 1989 is 25 times of the net factor payments of the year. They estimate foreign capital before and after 1989 using information of net exports and net factor payments of each year recursively.
} 
foreign capital and the ratio of domestic capital stock excluding land owned by the private non-financial sector to the total domestic capital stock excluding land. We find that the ratio of foreign capital owned by the private non-financial sector to tangible capital, excluding land owned by the same sector, is around $4 \%$ and $13 \%$ for the 80 s and during 1993-97, respectively.

\subsection{Appendix B}

This appendix is a reproduction of Section 3 of McGrattan and Prescott (2005) for readers' reference. The economy consists of two sectors; corporate sector denoted as 1 and non-corporate sector denoted as 2 . The population in period $t$ is denoted by $N_{t}$ and grows at rate $\eta$, so $N_{t+1}=(1+\eta) N_{t}$. The stand-in household's preferences are ordered by

$$
\sum_{t=0}^{\infty} \beta^{t} U\left(c_{t}, n_{t}\right) N_{t}
$$

where $c$ and $n$ are per capita consumption and labor supply, respectively. The tangible capital inputs are measured and are denoted by $k_{j m}$ for sector $j$. The intangible capital input in sector 1 is not measured and is denoted by $k_{1 u}$. Note that sector 2 has no intangible capital input.

The output of sector $j$ is denoted by $y_{j}$. Sector outputs are combined to produce a composite good which is used for either private consumption or government consumption or for one of the categories of investment,

$$
c_{t}+g_{t}+x_{1 m, t}+x_{1 u, t}+x_{2 m, t} \leq y_{t}=F\left(y_{1, t}, y_{2, t}\right)
$$

where $g$ is government consumption, $x_{j m}$ is gross investment in measured tangible capital in sector $j$, and $x_{1, u}$ is gross investment in unmeasured intangible capital in sector 1 .

The technology of sector 1 is described by

$$
\begin{array}{r}
y_{1, t} \leq f^{c}\left(k_{1 m, t}, k_{1 u, t}, z_{t} n_{1, t}\right) \\
k_{1 m, t+1}=\left[\left(1-\delta_{1 m}\right) k_{1 m, t}+x_{1 m, t}\right] /(1+\eta) \\
k_{1 u, t+1}=\left[\left(1-\delta_{1 u}\right) k_{1 u, t}+x_{1 u, t}\right] /(1+\eta) .
\end{array}
$$

Similarly,

$$
\begin{array}{r}
y_{2, t} \leq f^{n c}\left(k_{2 m, t}, z_{t} n_{2, t}\right) \\
k_{2 m, t+1}=\left[\left(1-\delta_{2 m}\right) k_{2 m, t}+x_{2 m, t}\right] /(1+\eta) .
\end{array}
$$

All technologies have constant returns to scale. In (9) and (12), $n_{j}$ is labor services in sector $j$ and the $\left\{z_{t}\right\}$ are technology parameters that grow at rate $\gamma$.

The life time budget constraint of households is written as

$$
\begin{aligned}
\sum_{t=0}^{\infty} p_{t}\{(1+ & \left.\left.\tau_{c}\right) c_{t}+v_{1 s, t}\left(s_{1, t+1}-s_{1, t}\right)+v_{2 s, t}\left(s_{2, t+1}-s_{2, t}\right)+b_{t+1}-b_{t}\right\} \\
& \leq \sum_{t=0}^{\infty} p_{t}\left\{\left(1-\tau_{d}\right) d_{1, t} s_{1, t}+d_{2, t} s_{2, t}+\left(1-\tau_{b}\right) r_{b, t} b_{t}+\left(1-\tau_{n}\right) w_{t} n_{t}+\psi_{t}\right\}
\end{aligned}
$$


where $\tau_{c}$ is the consumption tax rate, $\tau_{d}$ is the corporate distributions tax rate, $\tau_{b}$ is the capital tax rate, and $\tau_{n}$ is the labor income tax rate.

The value of shares held in corporate and non-corporate firms are $v_{1 s, t} s_{1, t}$ and $v_{2 s, t} s_{2}, t$, respectively, where $v$ is the price and $s$ is the number of shares held. The total number of shares outstanding is normalized to one in each sector. Government bonds are also held and denoted by $b$. The interest rate earned on these bonds is $r_{b}$. Transfers of the government are denoted by $\psi$.

The distributions paid to households are equal to what firms have after making new investments, paying wages, paying taxes, and receiving subsidies:

$$
\begin{aligned}
& d_{1, t}=p_{1, t} y_{1, t}-x_{1 m, t}-x_{1 u, t}-w_{t} n_{1, t}-\tau_{1 k} k_{1 m, t} \\
& \quad-\tau_{1}\left[p_{1, t} y_{1, t}-\hat{\delta}_{1 m} \hat{k}_{1 m, t}-\hat{\delta}_{1 x} x_{1 m, t}-x_{1 u, t}-w_{t} n_{1, t}-\tau_{1 k} k_{1 m, t}\right]+\tau_{x} x_{1 m, t} \\
& \begin{array}{r}
d_{2, t}=p_{2, t} y_{2, t}-x_{2 m, t}-w_{t} n_{2, t}-\tau_{2 k} k_{2 m, t} \\
\quad-\tau_{2}\left[p_{2, t} y_{2, t}-\hat{\delta}_{2 m} \hat{k}_{2 m, t}-\hat{\delta}_{2 x} x_{2 m, t}-w_{t} n_{2, t}-\tau_{2 k} k_{2 m, t}\right]+\tau_{x} x_{2 m, t}
\end{array}
\end{aligned}
$$

where $p_{j}$ is the price of goods in sector $j, w$ is the wage rate, $\tau_{j k}$ is the tax rate on property in sector $j, \tau_{j}$ is the tax rate on income in sector $j$, and $\tau_{x}$ is the investment tax credit. The term $\hat{\delta}_{1 m} \hat{k}_{1 m, t}+\hat{\delta}_{1 x} x_{1 m, t}$ is the allowed depreciation on tangible capital in sector $j$ and is used to compute taxable income. The depreciation rates $\delta_{j m}$ and $\delta_{j x}$ are policy parameters that can be set to effectively lower the price on new capital, as in the cases of U.S. and U.K.. The rate $\hat{\delta}_{j m}$ is the allowed rate of depreciation on sector- $j$ book "capital", which has a law of motion,

$$
\hat{k}_{j m, t+1}=\left[\left(1-\hat{\delta}_{j m}\right) \hat{k}_{j m, t}+\left(1-\hat{\delta}_{j x}\right) x_{j m, t}\right] /[(1+\eta)(1+\pi)] .
$$

The rate $\hat{\delta}_{j x}$ is the allowed rate of immediate expensing of investment in sector $j$.

In equilibrium, firms in the corporate sector choose capital and labor to solve

$$
\max \sum_{t=0}^{\infty} p_{t} d_{1, t}\left(1-\tau_{d}\right)
$$

subject to constraints (9)-(11) and (17) for $j=1$. Non-corporate firms solve a similar problem

$$
\max \sum_{t=0}^{\infty} p_{t} d_{2, t}
$$

subject to constraints (12)-(13) and a constraint analogous to (17) for $j=2$. Note that $d_{2, t}$ is non-corporate income net of taxes.

Government production is included in the non-corporate sector. Government purchases and transfers are financed by tax receipts and debt issues. The period $t$ government budget constraint must be satisfied each period and is given by

$$
g_{t}+\psi_{t}+r_{b} b_{t}=b_{t+1}-b_{t}+\text { all tax receipts. }
$$

Note that all tax rates are proportional in the model economy.

We now derive a estimation formula for the equilibrium value of corporate equity. 
Formula 1 (Proposition 4 in MP) On a balanced-growth path, the total value of corporate equity, $V_{t} \equiv v_{1 s, t} N_{t}$, satisfies

$$
V_{t}=\left(1-\tau_{d}\right)\left[\left(1-\tau_{x}-\tau_{\delta}\right) K_{1 m, t+1}+\left(1-\tau_{1}\right) K_{1 u, t+1}\right],
$$

where

$$
\tau_{\delta}=\tau_{1}\left[\hat{\delta}_{1 x}+\left(1-\hat{\delta}_{1 x}\right)\left(\frac{\hat{\delta}_{1 m}}{\left(i+\pi+\hat{\delta}_{1 m}\right)}\right)\left(\frac{(1+\pi)\left(1-\delta_{1 m}\right)-1+\hat{\delta}_{1 m}}{\gamma+\eta+\pi+\hat{\delta}_{1 m}}\right)\right] .
$$

Here, second-order terms are dropped, $i$ is real interest rate, and capital letters denote aggregates.

The value of intangible capital stock $K_{1 u, t+1}$ is unmeasured and must be estimated. We follow the MP's indirect approach. Assuming equal after-tax returns to tangible and intangible assets, we obtain inferred stock of intangible capital.

Formula 2 Then, on a balanced-growth path, the total value of intangible capital stock, $K_{1 u, t}$, satisfies

$$
K_{1 u, t}=\frac{1}{i-\gamma-\eta} \Pi_{1, t}-\frac{i}{\left(1-\tau_{1}\right)\left(\gamma+\eta+\delta_{1 m}\right)(i-\gamma-\eta)} X_{1 m, t}
$$

where second-order terms are dropped, capital letters denote aggregates, and $\Pi_{1, t}$ is aggregate profit in corporate sector. This equilibrium relation is derived from the definition of corporate profits as

$$
\text { Profit }_{t}=p_{1, t} y_{1, t}-w_{t} n_{1, t}-\delta_{1 m} k_{1 m, t}-\tau_{1 k} k_{1 m, t}-x_{1 u, t} .
$$

\section{References}

Alpanda, S. (2011): "Taxation, Collateral Use of Land and Japanese Asset Prices," Empirical Economics, forthcoming.

Ando, A. (2002): "Missing Household Saving and Valuation of Corporations: Inquiry into Japanese National Accounts I," Journal of the Japanese and International Economies, 16, 147-176.

Ando, A., D. Christelis, And T. Miyagawa (2003): "Inefficiency of Corporate Investment and Distortion of Savings Behavior in Japan," in Structural Impediments to Growth in Japan, ed. by M. Blomstrom, J. Corbett, F. Hayashi, and A. Kashyap, Chicago: University of Chicago Press, 155-190.

Braun, R. A., D. IkedA, And D. H. Joines (2009): "Saving and interest rates in Japan: Why they have fallen and why they will remain low," International Economic Review, 50, 291-321.

Chen, K., A. Imrohoroglu, and S. Imrohoroglu (2006): "The Japanese Saving Rate," American Economic Review, 96, 1850-1858. 
Corrado, C. And C. Hulten (2010): "How Do You Measure a "Technological Revolution"?" American Economic Review, 100, 99-104.

Corrado, C. A., C. Hulten, And D. Sichel (2009): "Intangible Capital and U.S. Economic Growth," Review of Income and Wealth, 55, 661-685.

Corrado, C. A., C. R. Hulten, And D. E. Sichel (2006): "Intangible Capital and Economic Growth," NBER Working Papers 11948, National Bureau of Economic Research, Inc.

Fukao, K., T. Miyagawa, K. Mukai, Y. Shinoda, and K. Tonogi (2009): "Intangible Investment In Japan: Measurement And Contribution To Economic Growth," Review of Income and Wealth, 55, 717-736.

Fukuta, Y. (2002): "A test for rational bubbles in stock prices," Empirical Economics, $27,587-600$.

Hayashi, F. (2006): "The Over-Investment Hypothesis," in Long-Run Growth and ShortRun Stabilization: Essays in Memory of Albert Ando, ed. by L. R. Klein, Cheltenham: Edward Elgar Publishing.

Hayashi, F. And T. Inoue (1991): "The Relation between Firm Growth and q with Multiple Capital Goods: Theory and Evidence from Panel Data on Japanese Firms," Econometrica, 59, 731-53.

Hayashi, F. AND K. Nomura (2005): "Can IT be Japan's savior?" Journal of the Japanese and International Economies, 19, 543-567.

Hayashi, F. And E. C. Prescott (2002): "The 1990s in Japan: A Lost Decade," Review of Economic Dynamics, 5, 206-235.

Hori, K., M. SAito, And K. Ando (2006): "What Caused Fixed Investment to Stagnate During the 1990s in Japan? Evidence from Panel Data of Listed Companies," The Japanese Economic Review, 57, 283-306.

Hoshi, T. And A. K. Kashyap (1990): "Evidence on q and Investment for Japanese Firms," Journal of the Japanese and International Economies, 4, 371-400.

IsHI, H. (2001): The Japanese Tax System, New York: Oxford University Press.

Ito, T. And T. Iwaisako (1995): "Explaining Asset Bubbles in Japan," NBER Working Papers 5358, National Bureau of Economic Research, Inc.

Marrano, M. G., J. Haskel, and G. Wallis (2009): "What Happened To The Knowledge Economy? Ict, Intangible Investment, And Britain'S Productivity Record Revisited," Review of Income and Wealth, 55, 686-716.

McGrattan, E. R. And E. C. Prescott (2000): "Is the Stock Market Overvalued?" Quarterly Review, Federal Reserve Bank of Minneapolis, 20-40. 
(2004): "The 1929 Stock Market: Irving Fisher Was Right," International Economic Review, 45, 991-1009.

- (2005): "Taxes, Regulations, and the Value of U.S. and U.K. Corporations," Review of Economic Studies, 72, 767-796.

(2010a): "Technology Capital and the U.S. Current Account," American Economic Review.

(2010b): "Unmeasured Investment and the Puzzling U.S. Boom in the 1990s," American Economic Journal: Macroeconomics.

NaKajima, T. (2008): "Asset Price Fluctuations in Japan: 1980-2000," Japan and the World Economy, 20, 129-153.

Nomura, K. (2004): The Measurement of Capital, Tokyo: Keio-Gijuku-DaigakuShuppan (in Japanese).

Ogawa, K. And S. Kitasaka (1998): Capital Markets and Business Cycles: An Empirical Analysis of the Modern Japanese Economy, Tokyo: Nihon-Keizai-Shimbun-Sha (in Japanese).

(1999): "Market Valuation and the q Theory of Investment," Japanese Economic Review, 50, 191-211. 
Figure 1: Capital-Output Ratio in Japan

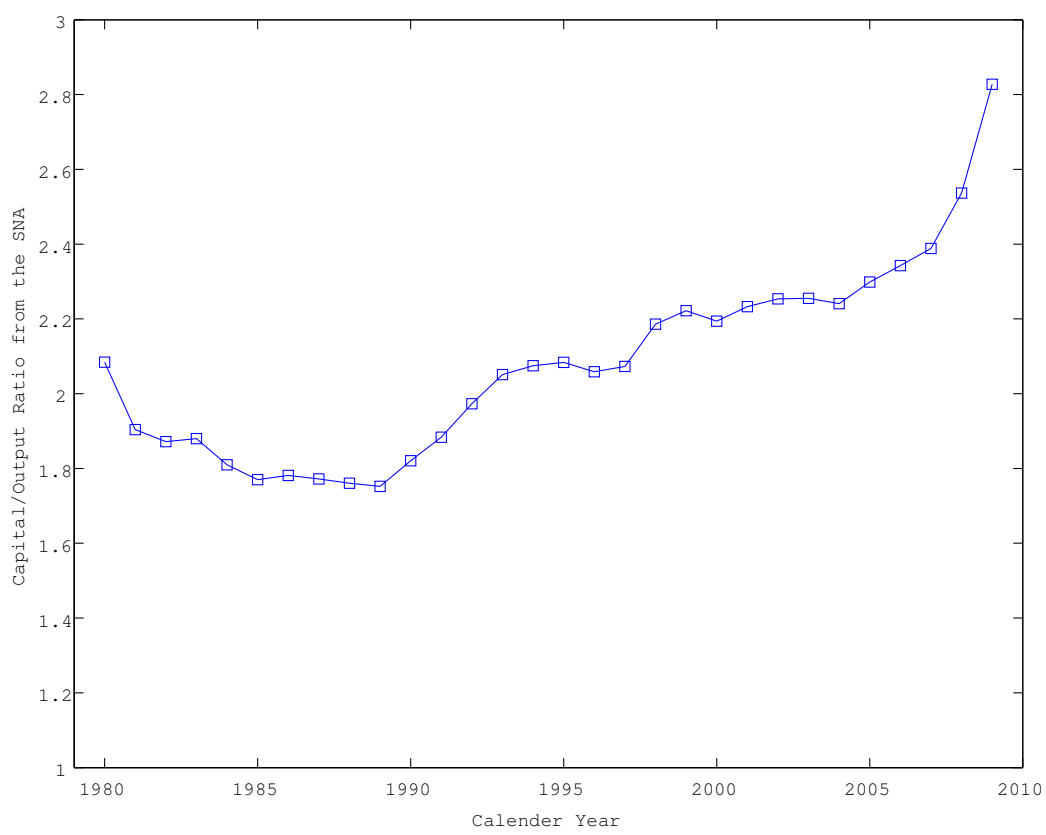

Note: The figure shows the capital-output ratio for Japan following the method of Hayashi and Prescott (2002) using 93SNA data.

Figure 2: Prices of Tangible and Intangible Capital

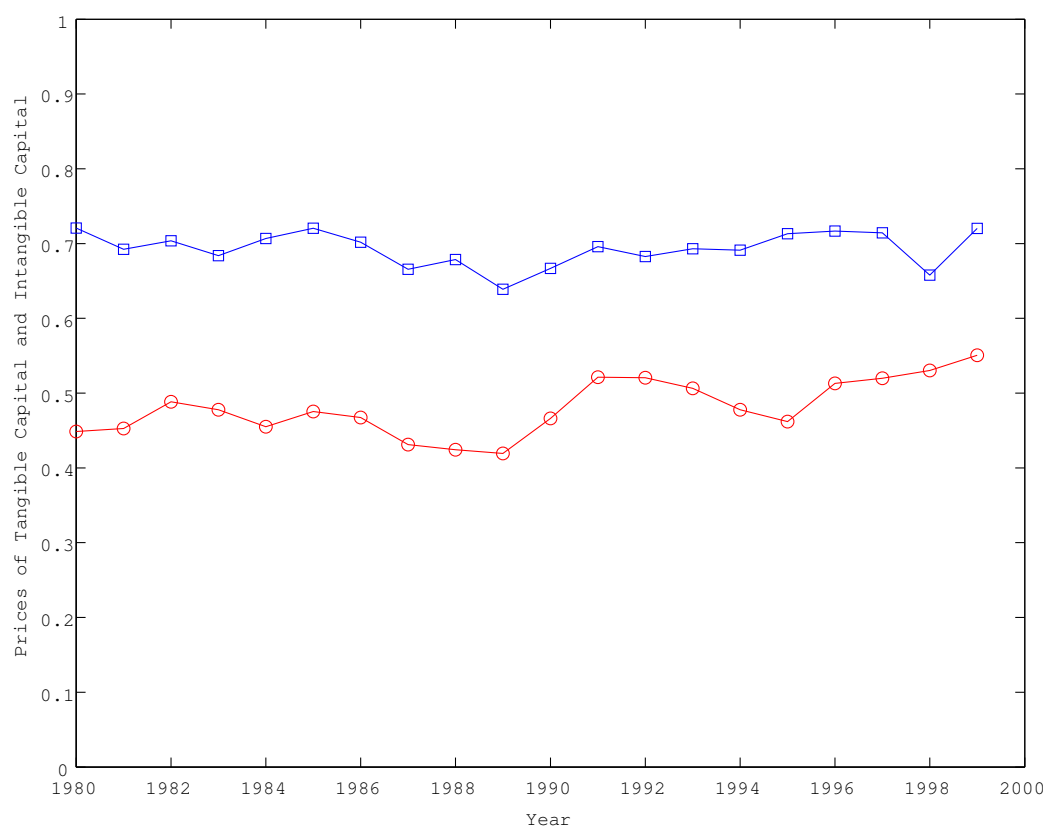

Note: The line with square dots shows the movement of the price of tangible capital, $\left(1-\tau_{d i s t}\right)\left(1-\tau_{x}-\tau_{\delta}\right)$. The line with round dots shows the movement of the price of intangible capital, $\left(1-\tau_{\text {dist }}\right)\left(1-\tau_{\text {corp }}\right)$. 


\section{Figure 3: Net Debt and Stock Value Movements in the CFD}
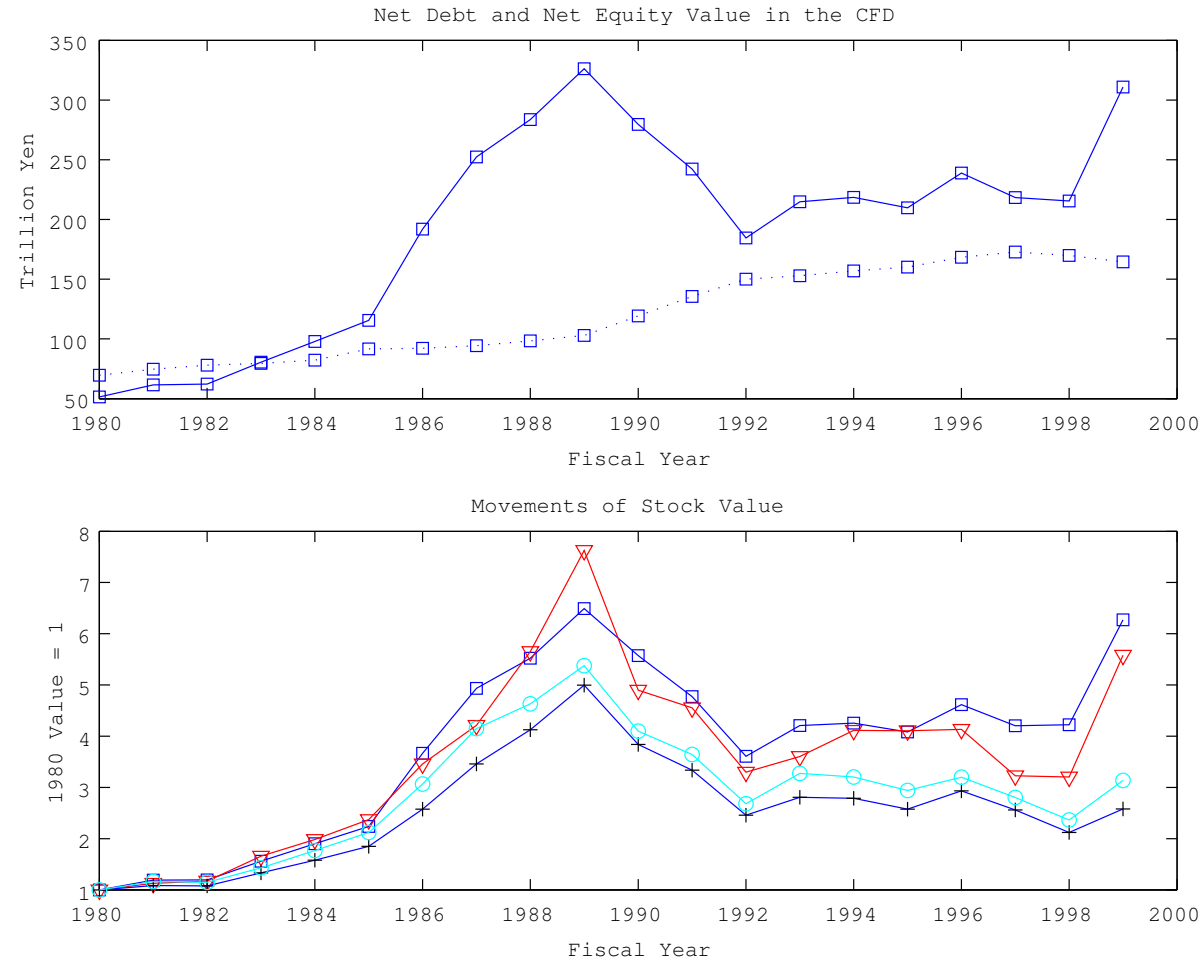

Top; The real line shows the movement of actual stock values net of the value of cross holding share and equity assets. The dashed line shows the movement of net debt value as non-equity financial liabilities minus non-equity financial assets. These aggregates are constructed using the CFD information.

Bottom; The line with square dots shows the movement of total actual value of outstanding equity from the CFD. We do not exclude the value of cross-holding shares. The line with triangle dots shows the movement of the same series from the SNA. The line with + dots shows the movement of Nikkei 225, and the line with round dots is for TOPIX. They are normalized to one for 1980 values. 
Figure 4: The Conversions of the CFD Book-Value Entries into the Market-Value Entries
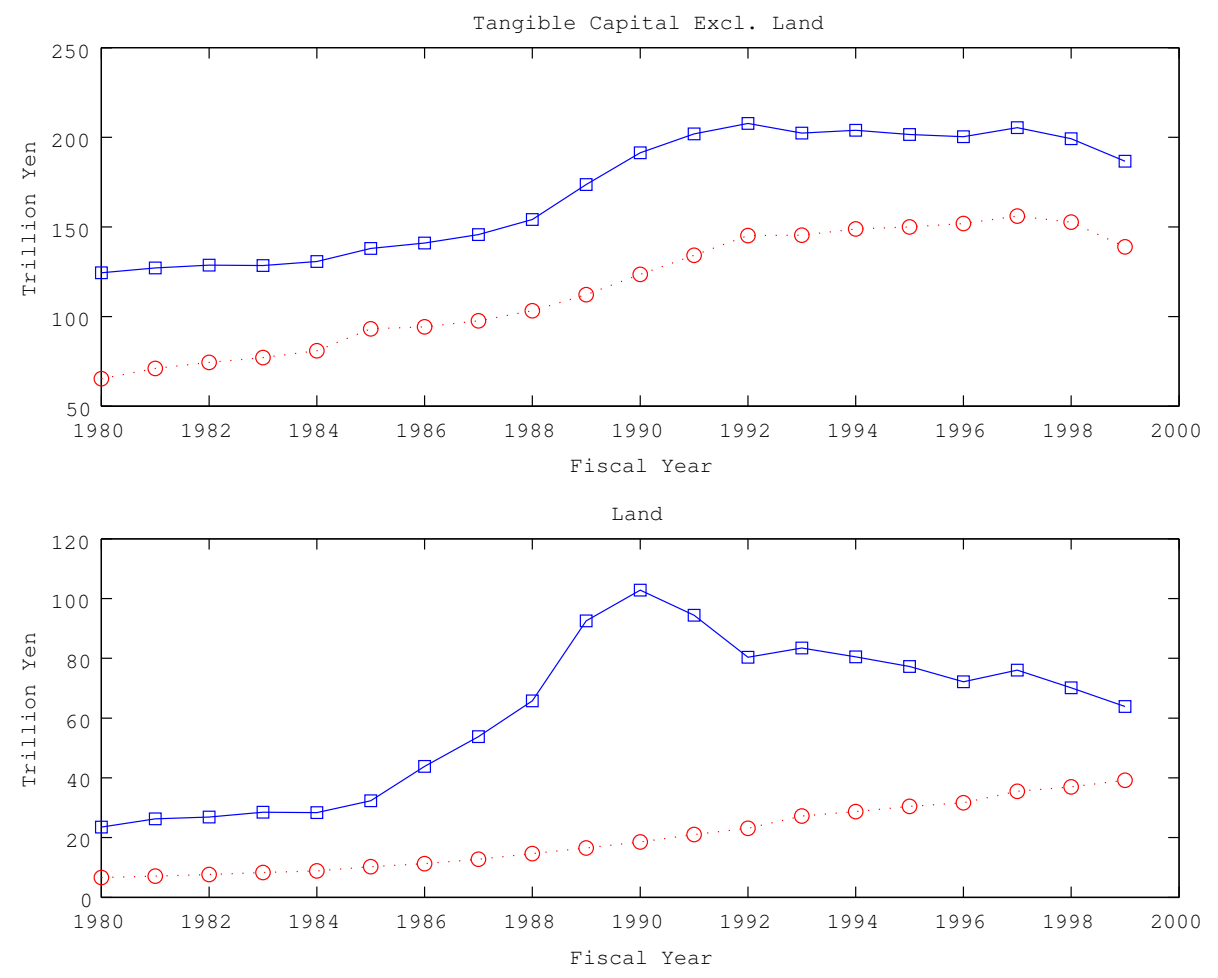

Note: Lines with square dots are for the movements of aggregates in a market-value basis. Dashed lines with round dots depict the movements of aggregates in a book-value basis. 
Figure 5: The difference in Coverage between the CFD and the SNA
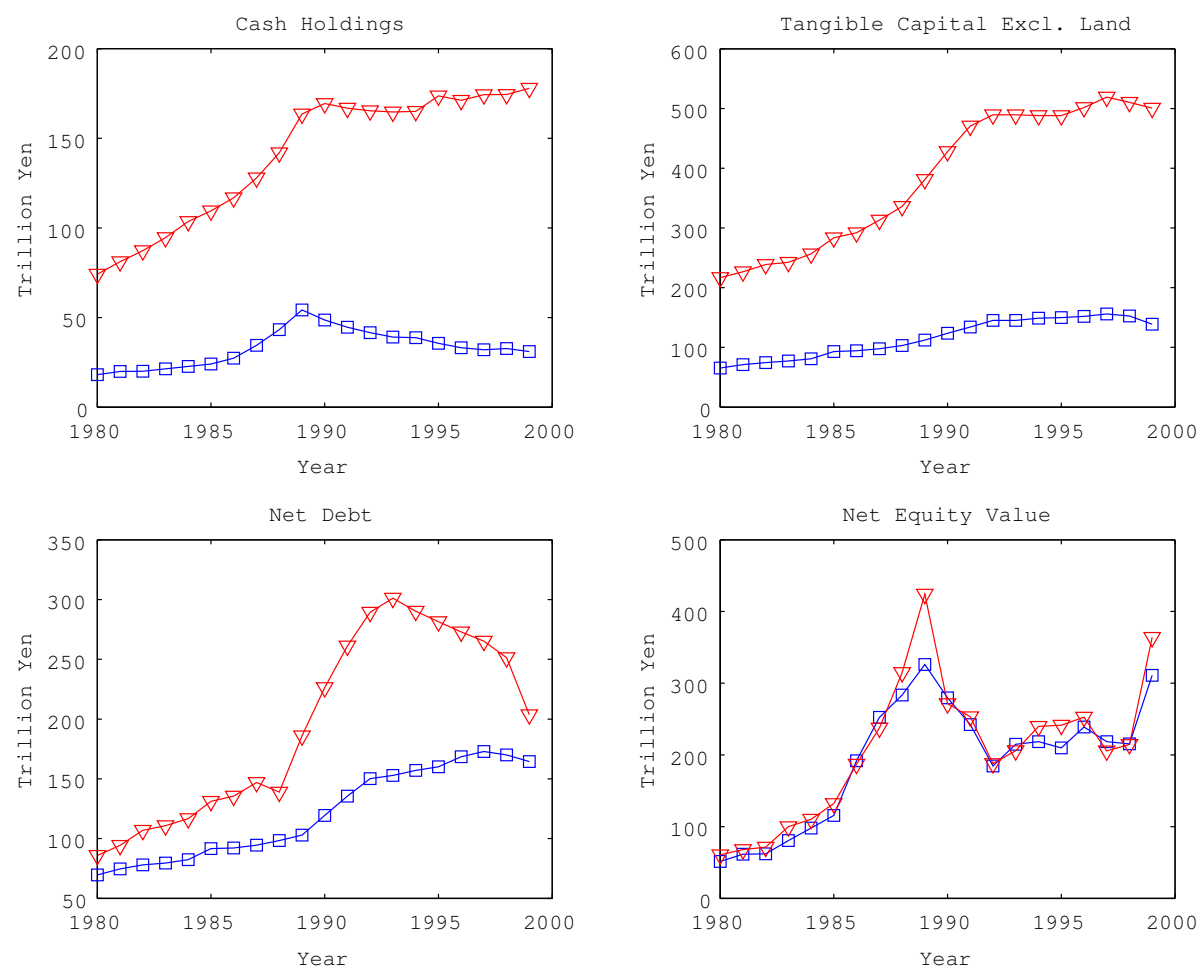

Note: Lines with triangle dots show variables from the SNA and the lines with square dots show variables from the CFD. The SNA data variables are in an end-of-calendar-year basis, and the CFD variables are in a fiscal year basis. 
Figure 6: Comparison the SNA with the FoF
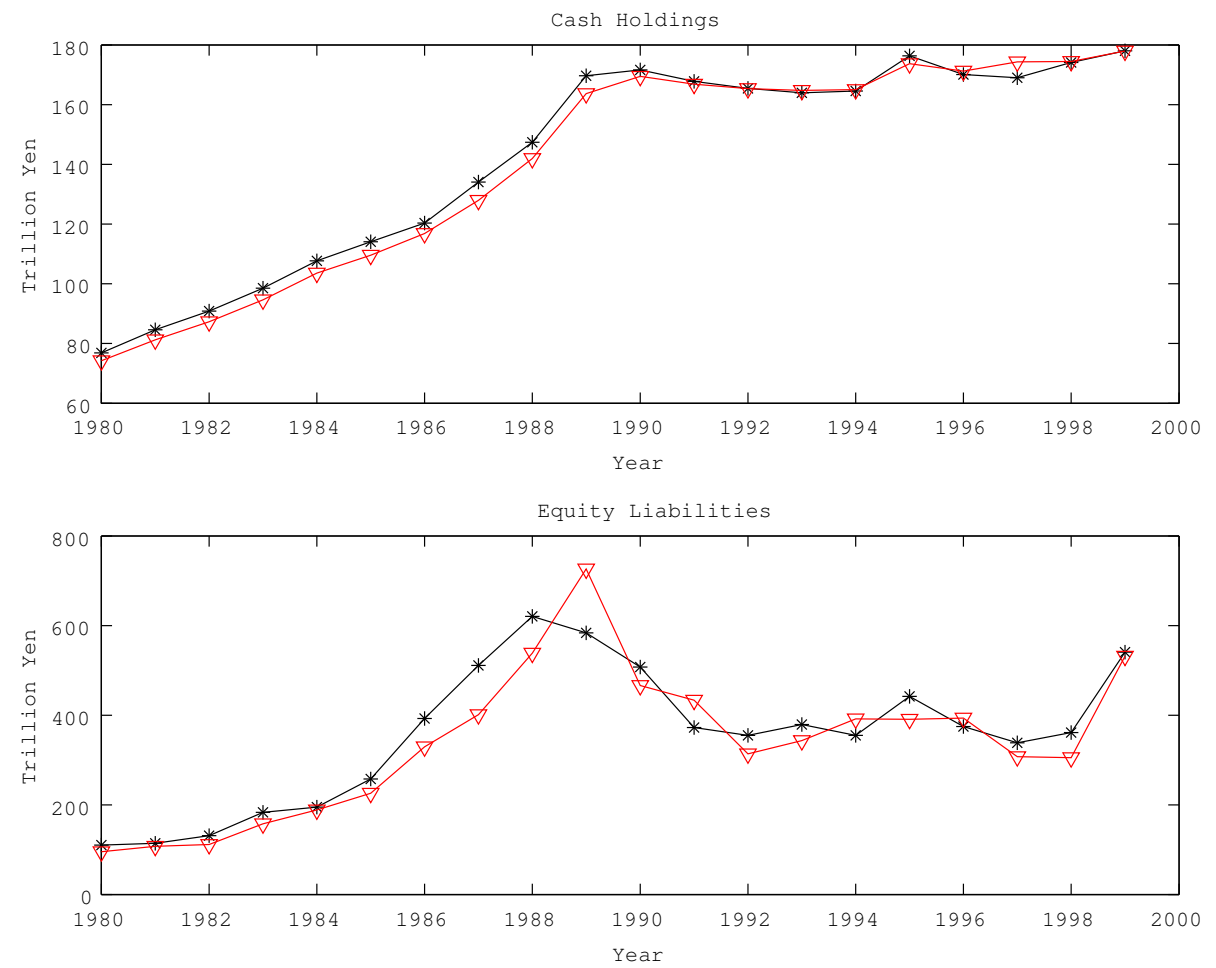

Note: Lines with triangle dots show variables from the SNA and the lines with $*$ dots show variables from the FoF. The SNA data variables are in an end-of-calendar-year basis, and the FoF variables are in a fiscal year basis. The coverage for cash holdings are the same for two data sets; all private non-financial corporations. The coverage of debt equity for the SNA is also all private non-financial corporations, where as that for the FoF is traded private non-financial corporations. 


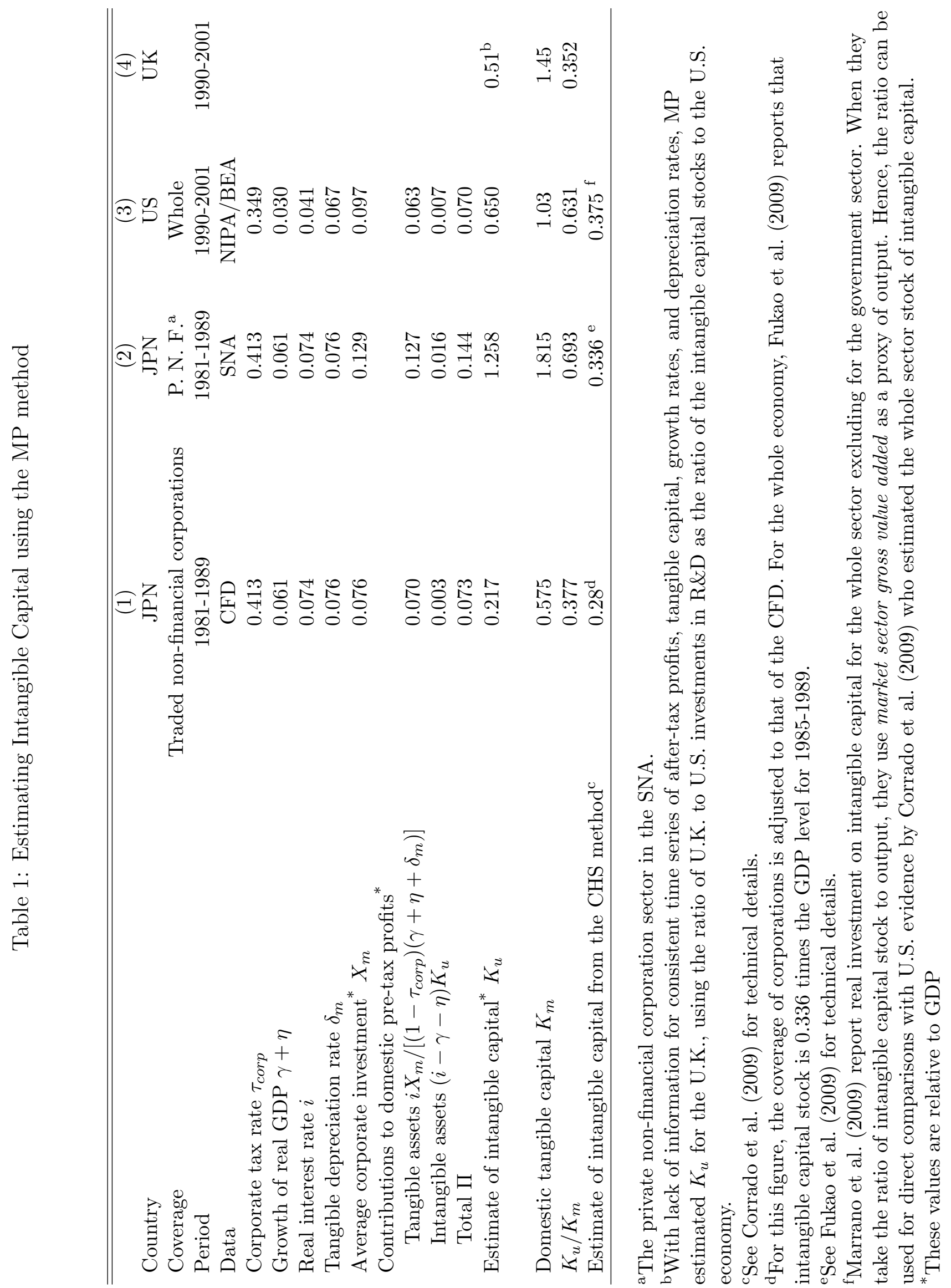




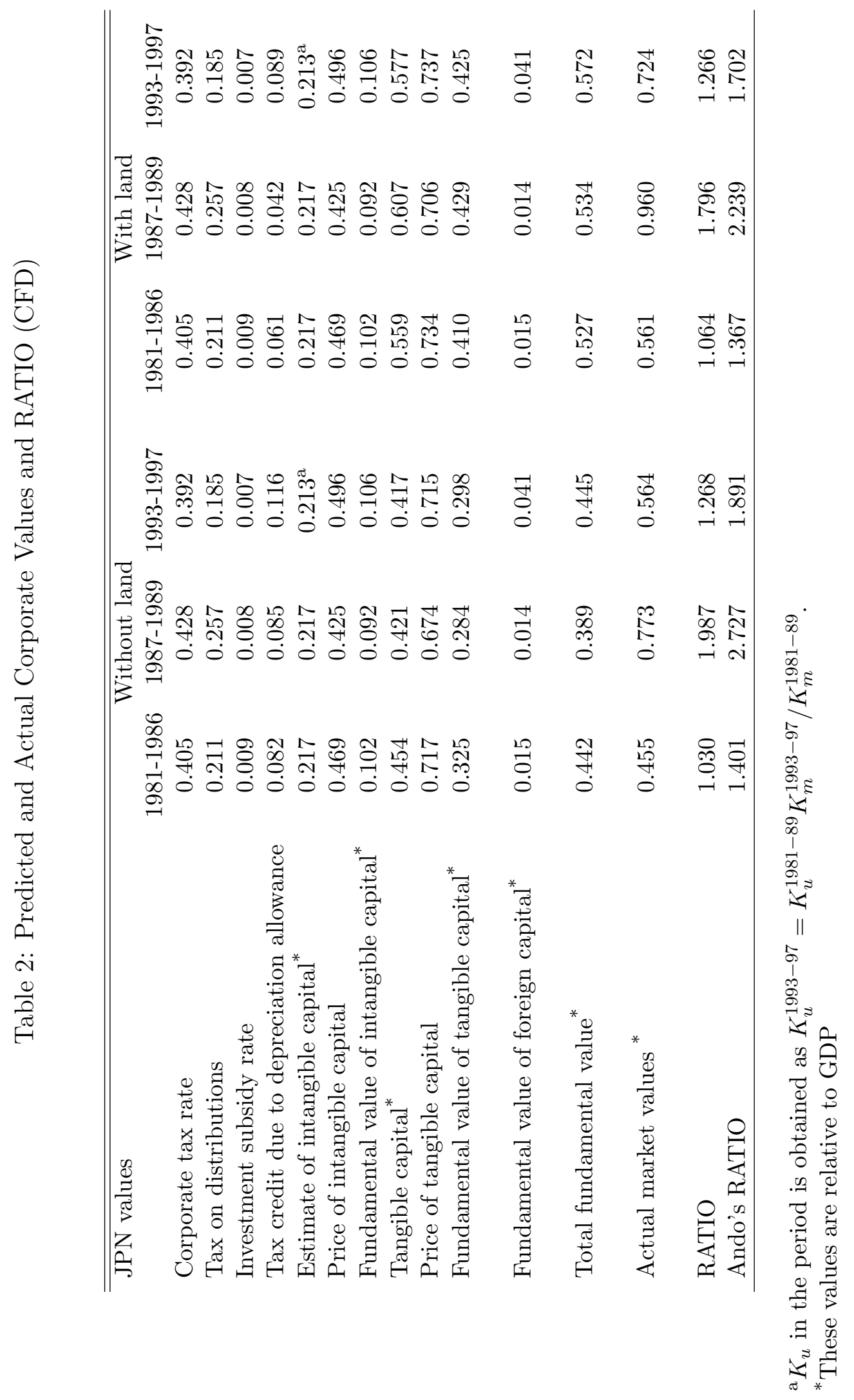

